\title{
The Triassic-Jurassic boundary in Asturias (northern Spain): Palynological characterisation and facies
}

\author{
E. Barrón ${ }^{a}$, J.J. Gómez ${ }^{b, *}$, A. Goy ${ }^{a}$, A.P. Pieren $b$ \\ a Departamento de Paleontología and UEI de Paleontología, Facultad de Ciencias Geológicas, Instituto de Geología Económica \\ (CSIC-UCM), Universidad Complutense, 28040 Madrid, Spain \\ b Departamento de Estratigrafía and UEI de Correlaciones Estratigráficas, Facultad de Ciencias Geológicas and \\ Instituto de Geología Económica (CSIC-UCM), Universidad Complutense, 28040 Madrid, Spain
}

\begin{abstract}
A palynological, biostratigraphic, sedimentological and sequence stratigraphy study of the Triassic-Jurassic transition in Asturias (northern Spain) was performed by logging and sampling the cores of two boreholes, the Cantavieyo and Vilorteo boreholes.

Four lithological units were differentiated and correlated. The lower unit, composed of mudstones and evaporites deposited in coastal lake to subaerial sabkha and distal alluvial environments, correlated in part with the Upper Triassic Keuper facies present in most of western Europe. The middle unit of well bedded carbonates corresponds to the Solis Member of the Gijon Formation. This unit was deposited on a shallow, subtidal to interand supratidal carbonate platform influenced by storms and with interbedded distal fan-delta facies. The TriassicJurassic boundary has been located within the carbonates of the Solis Member, which contain a Hettangian ammonite, Caloceras pirondii (Reynés), in tempestitic carbonates attributed to the upper part of this unit. The upper unit, the Barzana Member, is composed of mudstones, evaporites and carbonates, respectively, deposited in distal alluvial environments, in supratidal sabkha environments, and on a shallow subtidal to intertidal platform. Overlying the upper unit, or as a time equivalent of the Barzana Member, the Fabares Member is composed of a carbonate breccia with a lutitic matrix, interpreted as formed by the dissolution of the evaporites of the Barzana Member and the collapse of the originally interbedded carbonates and mudstones.
\end{abstract}

A total of 49 palynomorph taxa have been recorded: 20 spore taxa, 24 pollen taxa, 1 acritarch, 2 prasinophytes, and 2 dinoflagellate cysts. Three palynological assemblages (PA) have been distinguished. PA1, which is typically Rhaetian, corresponds to the Rhaetipollis germanicus Zone. PA2 can be Rhaetian and/or Hettangian in age. PA3, which is Hettangian in age, partly corresponds to the Kraeuselisporites reissingeri Zone. These zones have been correlated with similar zones in northwestern Europe.

Palaeoecological analysis of the palynomorph assemblages indicates marked palaeofloral renewal, from diversified, Late Triassic xerophilous plants to an impoverished palaeofloral community at the Triassic-Jurassic transition. The latter was composed of a poorly diversified group of conifers and ferns. The arid climate of the Late Triassic was followed by a short, humid event at the beginning of the Hettangian, during which the renewal and important recovery of vascular cryptogams and conifers occurred. The later predominance of xerophilous species in the Hettangian indicates a recovery of arid climatic conditions.

After the turnover at the end of the Triassic, and especially during the Hettangian, the recovery of new species is well marked. Of a total of 21 palynomorphs, 7 species did not surpass the base of the Triassic Jurassic transition, 6 species appeared in this transition, and 22 species appeared in the Hettangian, marking an outstanding phase of recovery for the plants that generated the studied palynomorphs. 


\section{Introduction}

The biological and geological events that occurred near the Triassic-Jurassic boundary (TJB) are currently one of the major areas of interest in Geology. As many authors have indicated, the mass extinction events at the transition between these systems represent an episode of major global change in the Phanerozoic (Marzoli et al., 1999, 2004; Ward et al., 2001; Pálfy et al., 2001; Tanner et al., 2001, 2004; Hesselbo et al., 2002, 2004; Beerling, 2002; Guex et al., 2004). The end-Triassic mass extinction resulted in the loss of over $76 \%$ of the species living at that time (Raup, 1992), including 30\%of all marine genera, $50 \%$ of all tetrapod species, and $95 \%$ of all megafloral species, as well as a marked turnover of microflora in the Northern Hemisphere (McElwain et al., 1999).

A correlation of the changes that took place in the transition between these systems requires precise, biochronological and stratigraphic resolution data at the local level. Evidence from different areas can then be compared. In Asturias, a region of northern Spain (Fig. 1), the Permian and Triassic are represented by a monotonous succession of clastic and evaporitic sediments (Gutiérrez Claverol and Manjón, 1984; Pieren et al., 1995), while the Jurassic succession is mainly represented by a marine carbonate platform (Suarez Vega, 1969, 1974; Valenzuela et al., 1986; Valenzuela Fernández, 1988) followed by a lutitic, evaporitic and carbonate unit (Barrón et al., 2002). Based on palynological studies, attempts were made by Martínez García et al. (1998) and Barrón et al. (2002) to define the TJB in outcrops, but some of the evaporitic units are strongly perturbed at the surface or near-surface due to dissolution of the evaporitic components and the subsequent collapse of the section. Detailed stratigraph-ic analysis is therefore impossible.

During the evaluation of Carboniferous coal reserves at La Camocha Mine, $5 \mathrm{~km}$ south of Gijon (Fig. 1), two boreholes were spudded: the Cantavieyo borehole and the Vilorteo borehole. These provide an excellent opportunity to study an unperturbed section of the Triassic-Jurassic transition in this area, and under excellent outcrop conditions. This paper reports the results of an integrated biostratigraphic, sedimentological and sequence stratig-raphy study based on core logging and core sampling of these two boreholes. Special attention was paid to the study of the palynomorphs as the main biostratigraphic

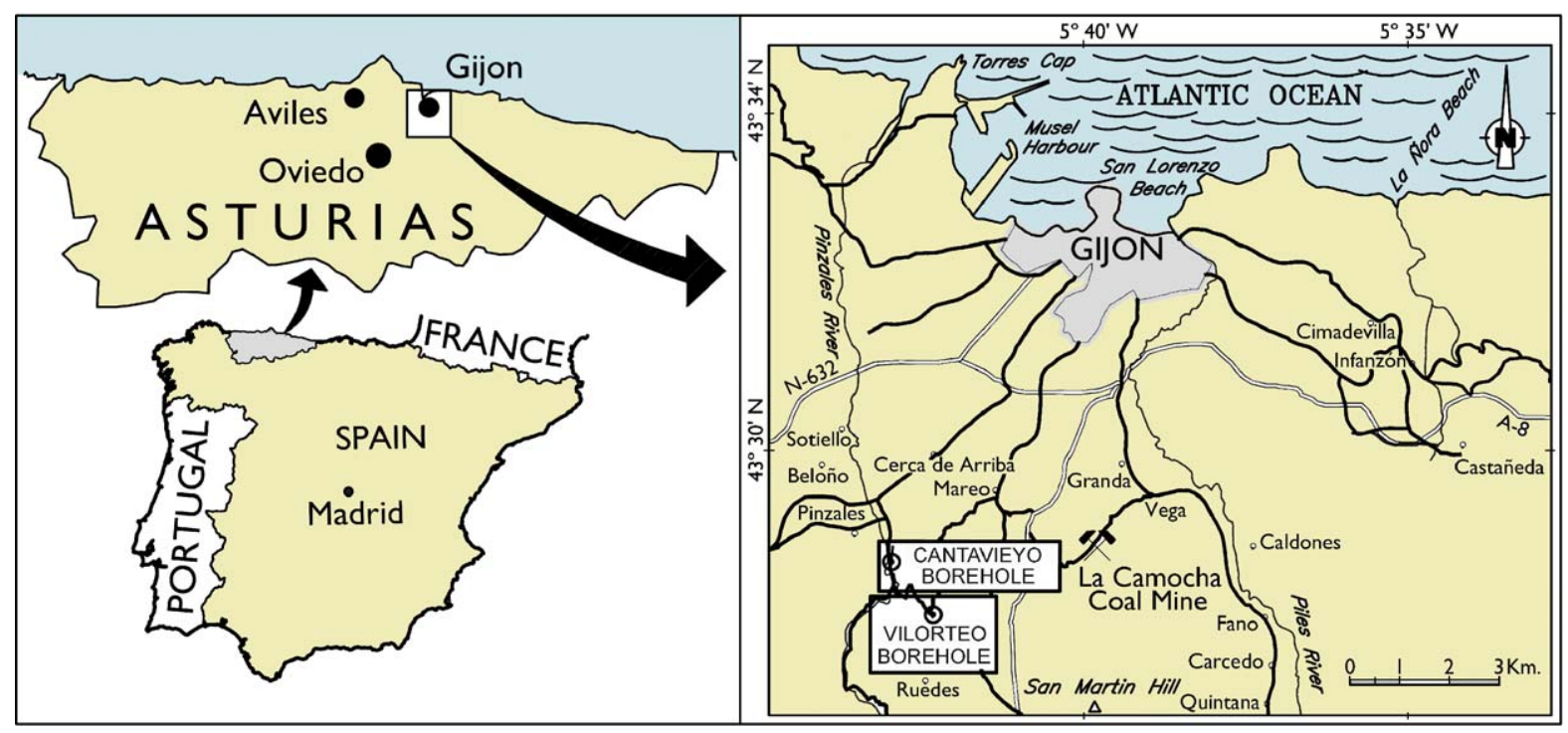

Fig. 1. Location of the study area, showing the position of the Cantavieyo and Vilorteo boreholes. 
tool. The palaeoecological conditions of the boundary between the two systems were also examined.

\section{Geological setting}

The Triassic-Jurassic deposits of Asturias (which are extensively developed in this part of northeastern Spain) represent the northwesternmost outcrops of the Iberian platform system (Fig. 2). Palaeozoic rocks crop out over most of region, except for the northern part where the Mesozoic and Cenozoic cover forms the main geolog-ical feature (Fig. 2). The Cantavieyo and Vilorteo boreholes were drilled in one of the main graben structures of the area, but they still are on the different blocks of a major fault responsible for thickness and facies changes, especially during Permian. Basement rocks are intersected at a depth of $585 \mathrm{~m}$ in the Cantavieyo borehole and at $638 \mathrm{~m}$ in the Vilorteo
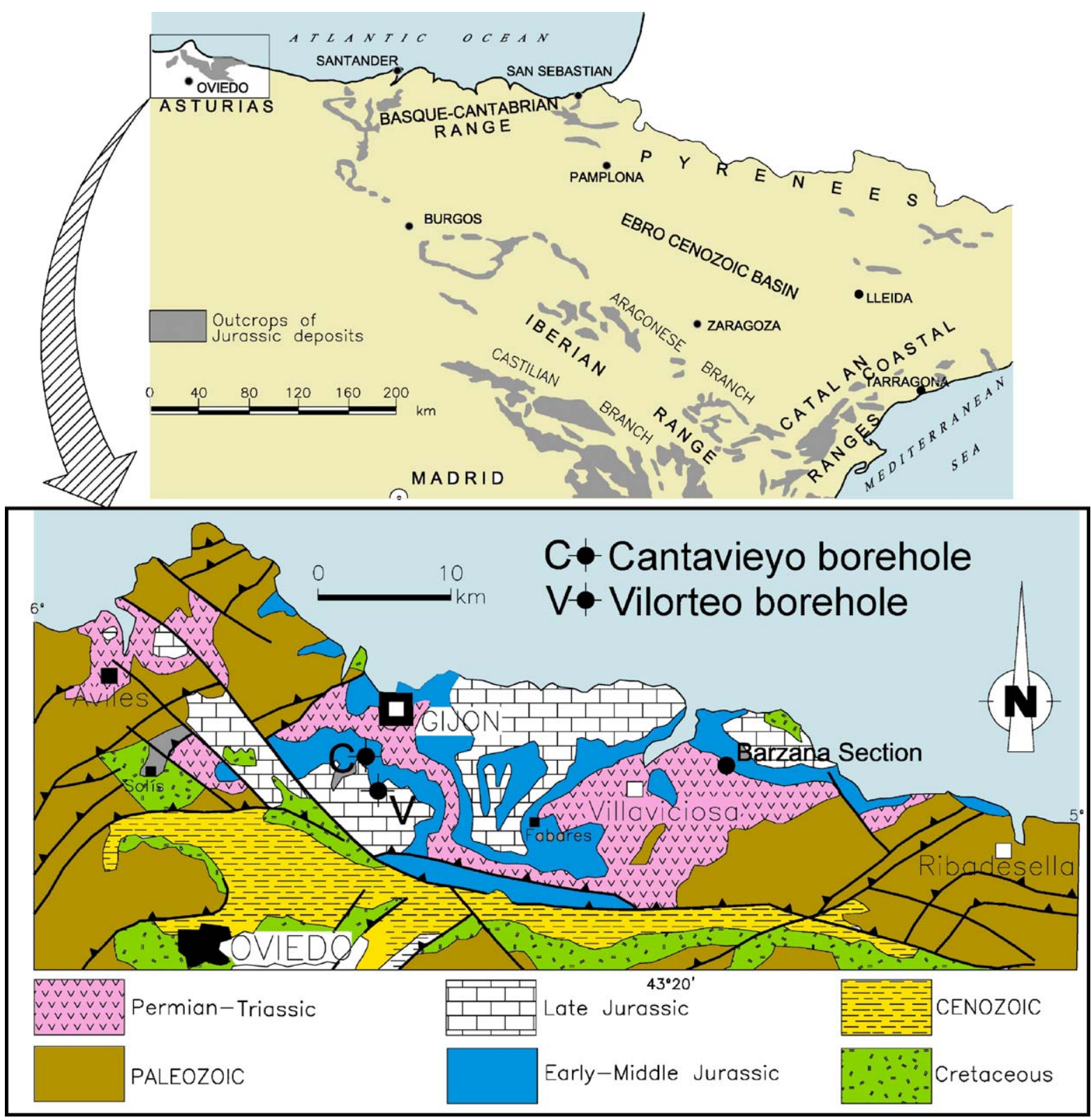

Fig. 2. Upper part: distribution of outcrops of Jurassic deposits in northern and eastern Spain. Lower part: geological sketch of the Mesozoic outcrops of Asturias, and the location of the Cantavieyo and Vilorteo boreholes and other localities cited in the text. 
borehole, below the Lower Jurassic to Permian section (Pieren et al., 1995).

The dating of the TJB is difficult over most of the Iberian platform system. The finding of an ammonite, Caloceras pirondii (Reynés), in Asturias (southwest of Aviles; see Fig. 2) b y Llopis (1961), later studied by Dubar et al. (1963), allows dating of the upper part of the lower Hettangian deposits in this portion of the platform. However, this ammonite was found ex situ and, as a consequence, the dating of the TJB remained inaccurate. Despite this uncertainty, and even before knowing in which lithological unit the TJB was contained, some authors postulated the presence of a regional stratigraph-ic discontinuity or even an angular unconformity at the boundary of the two systems (Aurell et al., 2002, 2003; Robles et al., 2004). However, this has never been supported by biostratigraphic data.

In Asturias, the TJB has traditionally been assigned to the so-called "Transition beds of the Caravia beach", which are overlain by the Solis and Sotiello Members of the Gijon Formation (Fig. 3; Suárez Vega, 1974). However, a palynological study of one sample by Martínez García et al. (1998) showed that these transition beds are Late Rhaetian in age. Later studies by Barrón et al. (2002), and correlation with the successions found in the Cantavieyo and Vilorteo boreholes in this work, show that the TJB is located within a well bedded carbonate unit with interbedded mudstones, equivalent to the Solis Member (Fig. 3; Barrón et al., 2002). Overlying the carbonate unit, alternating mudstones, carbonates and evaporites (better preserved in the subsoil) were recorded. Nevertheless, the time equivalent of this upper unit in the surface outcrops is represented by a chaotic breccia of carbonates in a lutitic matrix (Fig. 3; Barrón et al., 2002; González et al., 2004).

\section{Materials and methods}

The stratigraphic successions of the sediments containing the Triassic-Jurassic transition intersected in the Cantavieyo and Vilorteo boreholes were obtained from a detailed study of the recovered cores. Both boreholes were inclined $\left(17.5^{\circ}\right)$ and intersected dipping strata $\left(3.5^{\circ}\right)$. The depths obtained for the boundaries of every intersected unit were recalculated into real thicknesses (Figs. 4 and 5). The lithologies were characterised, sedimentary structures identified and logged, and the sequence organization of the deposits interpreted.

For the palynological study, 31 samples from the Vilorteo borehole and 18 samples from the Cantavieyo borehole were examined. The fact that samples were obtained from corings prevented potential contamination, which cannot be discarded in surface samples and well cuttings. Samples were prepared following the Phipps and Playford (1984) method, based on acid attack $\left(\mathrm{HCl}, \mathrm{HF}, \mathrm{HNO}_{3}\right)$ at high temperature. The palynomorph concentration was estimated by passing the resulting residues through $500,250,75,50$ and 12 $\mu \mathrm{m}$ sieves. Slides were prepared by mounting the palynomorphs in glycerine jelly. They were then identified and at least 300 counted for each sample on four slides to determine the species ratios. Thirty-nine samples, 24 from the Vilorteo borehole and 15 from the Cantavieyo borehole, yielded satisfactory results.

\section{Lithostratigraphy, sedimentology and sequence organization}

The cores from the two boreholes show a similar stratigraphic succession. Four lithological units were

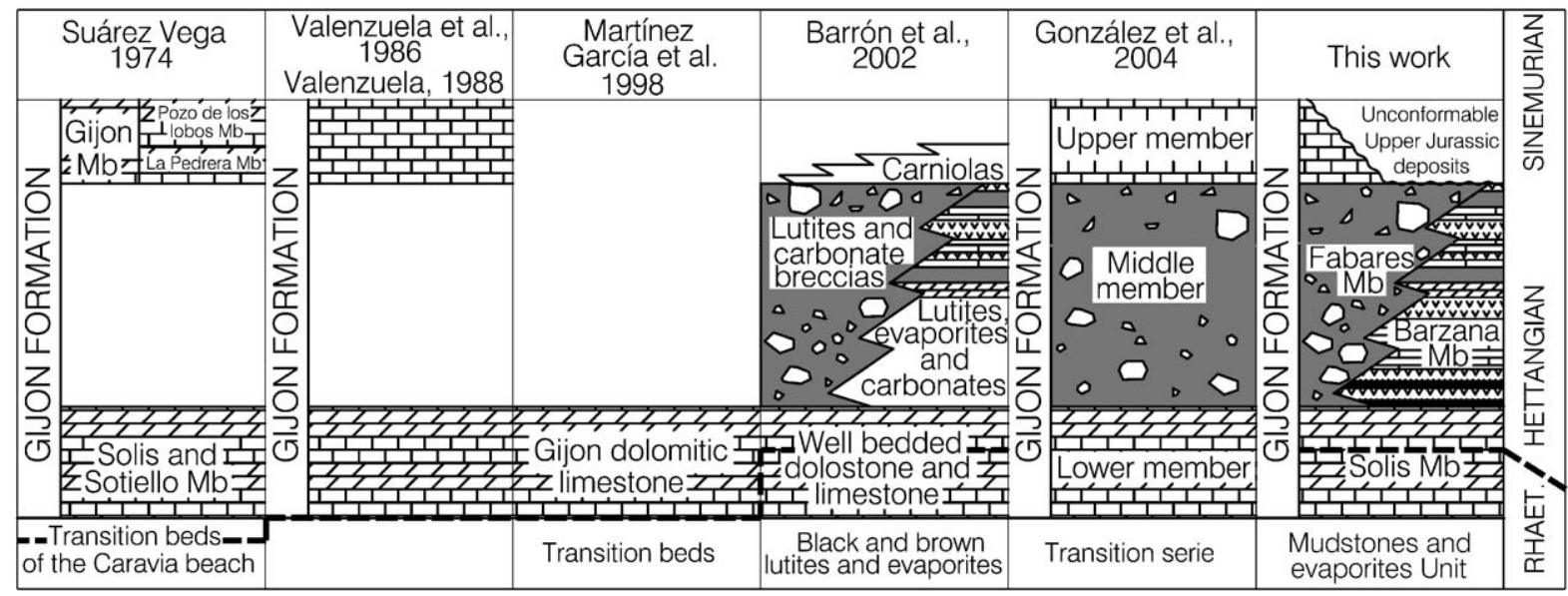

Fig. 3. Stratigraphic succession of the Triassic-Jurassic deposits of Asturias (as reported by different authors). 


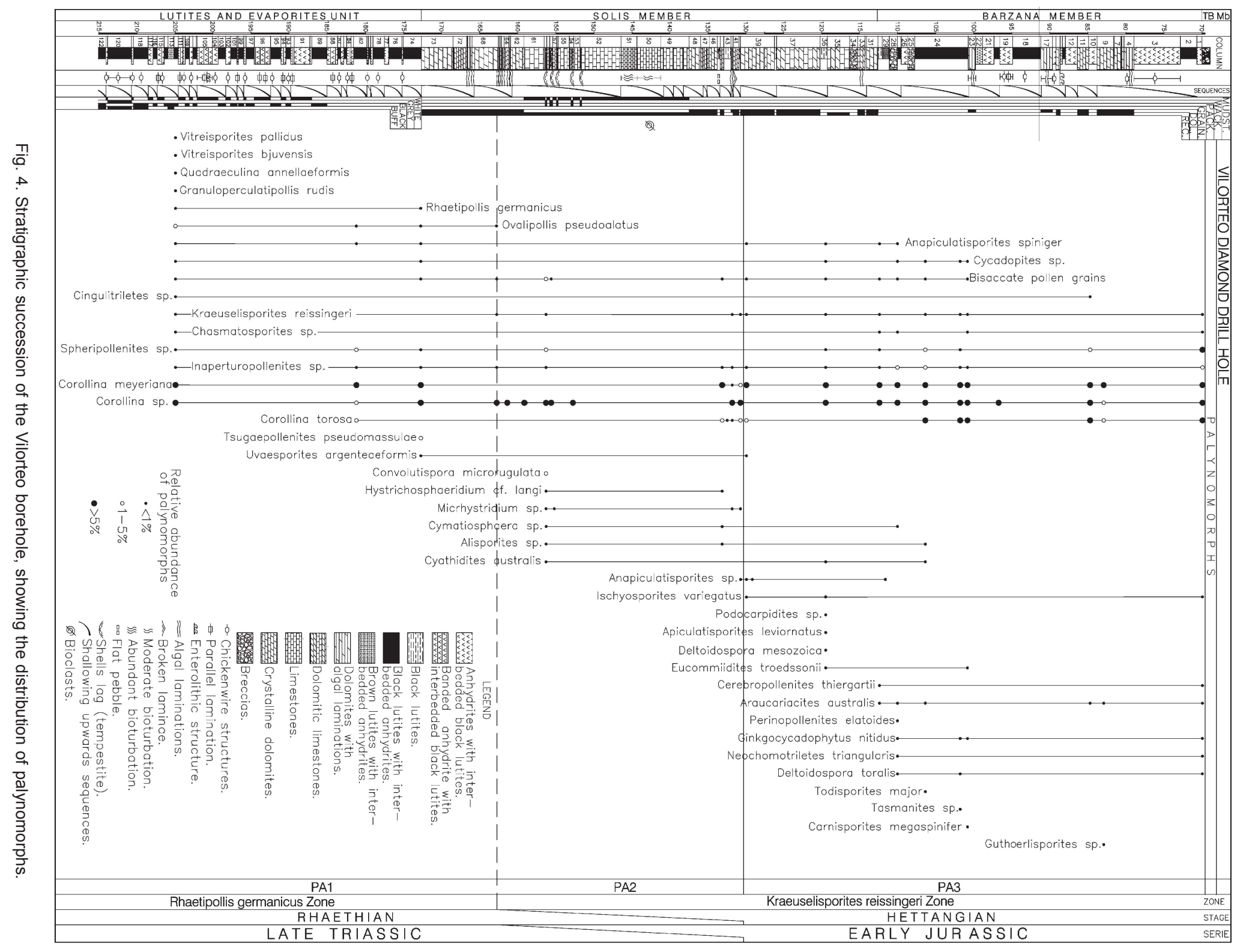




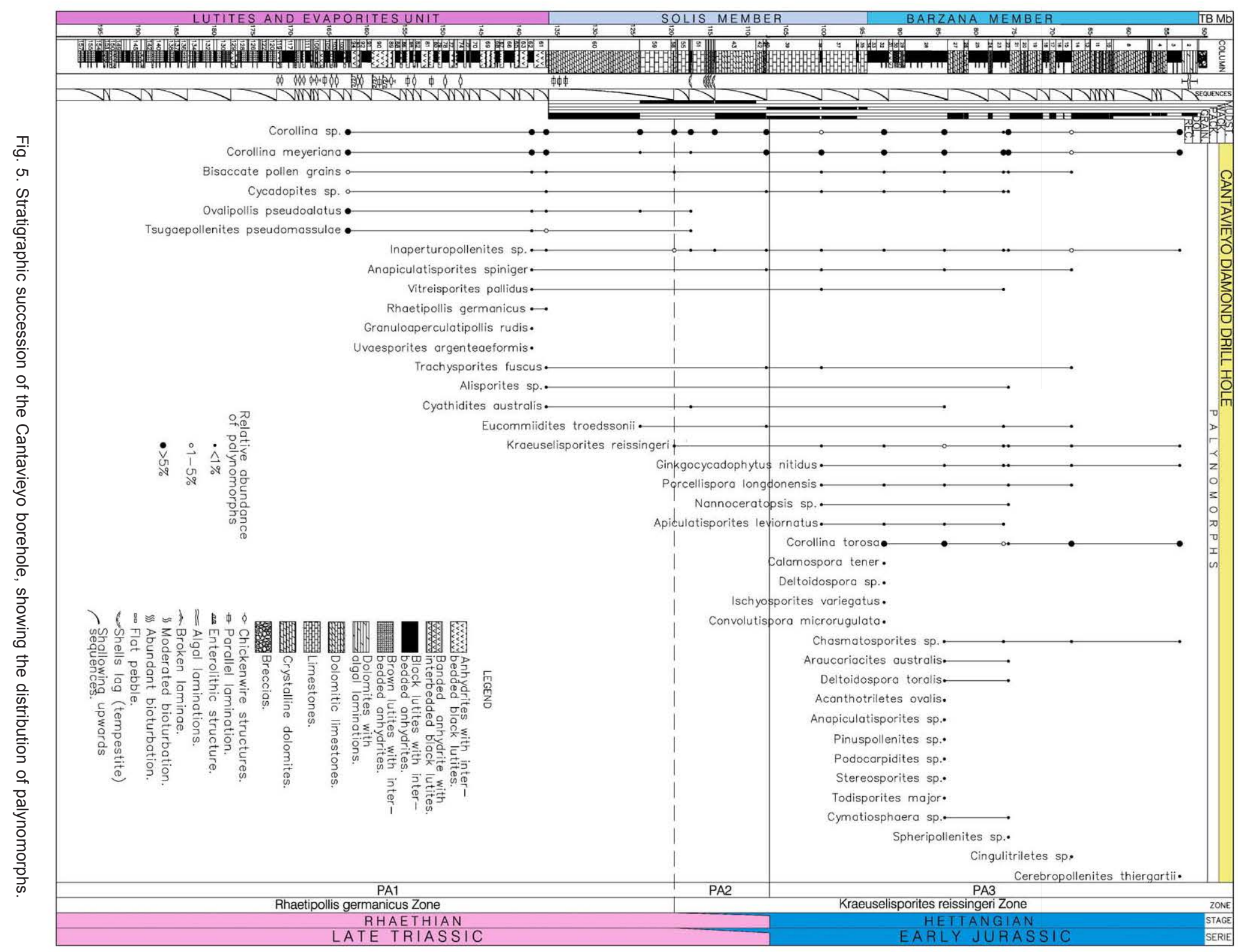


differentiated and correlated (Figs. 3-5). From bottom to top, the lower unit of mudstones and evaporites partly correlates with the Keuper facies. The middle unit is composed of well bedded carbonates and corresponds to the Solis Member of the Gijon Formation. The upper unit of mudstones, evaporites and carbonates is defined in this work as the Barzana Member of the Gijon Formation. The time equivalent of the Barzana Member is a carbonate breccia with a lutitic matrix, defined here as the Fabares Member of the Gijon Formation.

\subsection{Mudstones and evaporites unit}

The lowermost unit, which crops out in the surroundings of the drilling area (Manjón and Gutiérrez Claverol, 1991), is composed of an irregular alternation of mudstones and evaporites. The mudstones are brown and dark grey to black, and commonly contain thin, interbedded layers of anhydrite. The evaporite intervals are composed of anhydrites and gypsum, massive or banded, and commonly contain thin layers of inter-bedded mudstones. The different lithological intervals shown in Figs. 4 and 5 are based on the predominance of one or the other lithology. The anhydrites commonly show laminated and nodular chickenwire structures and occasionally enterolithic fold structures.

This unit is organised in shallowing-upwards sequences in which evaporite-dominated intervals form the lower part of the sequence. Mudstones with interbedded anhydrites form the upper part. Within the evaporites, the succession from bottom to top shows a lower part containing massive to laminated evaporites deposited in coastal lake subaqueous depositional environments (Warren and Kendall, 1985; Steinhoff and Strohmenger, 1999), and an upper part with nodular structures and enteroliths, indicating subaerial sabkha environments (Holser et al., 1988; Kendall and Har-wood, 1996). The deposits dominated by mudstones at the upper part of the sequence were interpreted as distal alluvial facies.

\subsection{Solis Member}

The intermediate unit intersected in the drillholes, which contains the TJB, is composed of a 41 to 60 m-thick succession of well bedded dolostones and lime-stones with interbedded thin layers of mudstones. This unit corresponds to the Solis Member. Thin layers of bivalve-rich lime packstones were also quite common, both in the boreholes and in surface sections. The specimen of Caloceras pirondii (Reynés) found by
Llopis (1961) and studied by Dubar et al. (1963) was found in this facies, suggesting that this fossil was affected by reworking and displacement before final burial. The lack of any signs of substantial sedimentary discontinuities in the outcrops and boreholes, and the marked lateral continuity of this unit, does not support the presence of an internal unconformity marking the TJB.

Carbonate breccias are uncommon, but present in the middle-upper part of the unit. The well bedded carbonates of the Solis Member appear in shallowing-upwards sequences. The lower carbonate part (some-times bioturbated) was deposited on a shallow subtidal carbonate platform. Bivalve-rich layers forming shell lags are interpreted as tempestitic deposits. The middle part is composed of carbonates with algal laminations, broken laminae and flat pebble breccias deposited in intertidal to supratidal environments. The upper part of the sequence is composed of mudstones, which represent distal fan-delta deposits.

\subsection{The Barzana Member}

The upper unit is composed of an irregular alternation of mudstones, evaporites and carbonates with interbedded breccias, for which the formal name of the Barzana Member is here proposed. The type section of the Barzana Member is located in the road cut of the national road 632 between Villaviciosa and Colunga, located south of the Barzana village. The mudstones of the Barzana Member are frequently dark grey to black and contain thin beds of evaporites and dolomites. The evaporites are composed of anhydrite and gypsum (occasionally banded and showing chick-enwire structures and enterolithic folds), which some-times show interbedded mudstones. The proportion of evaporites in this unit is greater in the Vilorteo borehole; carbonates predominate in the Cantavieyo borehole. These carbonates are mainly thin bedded dolostones, sometimes with algal laminations. The breccias are very minor components of the Barzana Member. The preserved part of the unit is only $7 \mathrm{~m}$ thick in the Barzana surface section (Barrón et al., 2002), while it reaches a thickness of $43 \mathrm{~m}$ in the boreholes. The Barzana Member is organised in shallowing-upwards sequences, the lower part of which is represented by carbonates deposited in shallow subtidal to intertidal platform environments, the middle part of which is composed of evaporites mainly deposited in supratidal sabkha environments, and in which the lutitic lithologies of the upper part represent distal alluvial systems. 


\subsection{The Fabares Member}

A thick breccia unit, for which the name of the Fabares Member is here proposed, was intersected in the upper part of the boreholes and was visible in many surface outcrops, either overlying the Barzana Member or as its lateral equivalent. The type section of the Fabares Member is located in the road cut of the kilometres 4 to 5 of the Highway A-6 between Villaviciosa and Oviedo. The Fabares Member, is composed of gravel to block-size, mud-supported carbonate breccias in a grey to black and brown lutitic matrix. The breccia components were distributed in very irregular chaotic bodies, in which carbonate fragments are very badly sorted (Barrón et al., 2002). In surface outcrops, this breccia sometimes overlies the well bedded dolomites and limestones of the Solis Member, indicating that the breccia is at least in part the time-equivalent of the mudstones, evaporites and carbonates of the Barzana Member. This correlation supports a collapse origin for this breccia unit due to dissolution of the interbedded evaporites and the subsequent collapse of the carbonates and mudstones (Barrón et al., 2002; González et al., 2004). The thickness of the Fabares Member is more than $100 \mathrm{~m}$ in the Barzana section, more than $70 \mathrm{~m}$ in the Vilorteo borehole, and more than $50 \mathrm{~m}$ in the Cantavieyo borehole. The chaotic character of this breccia rendered detailed stratigraphic analysis impossible. Consequently, no samples for palynological studies were collected from this unit.

\section{Palynological study}

The samples from the lutitic levels of the different lithostratigraphic units described above were the most productive in terms of palynomorphs (Figs. 4 and 5). A total of 20 spore and 24 pollen types, 1 acritarch, 2 prasinophytes and 2 dinoflagellate cysts (Table 1) were found. 41 taxa were recorded in the Vilorteo borehole (Fig. 4) and 38 in the Cantavieyo borehole (Fig. 5). Miospores were the primary focus of the study due to their predominance in the analyzed samples. A complete systematic study of the palynofloras was not considered since the majority of the recorded taxa have been sufficiently treated elsewhere (Evitt, 1961; Schulz, 1967; Morbey, 1975; Schuurman, 1976; Lund, 1977; Guy-Ohlson, 1986).

The palynological assemblages at the Rhaetian-Hettangian transition in the studied boreholes are characterised by wind-dispersed pollen grains related to gymnosperms. The genus Corollina was the most abundant palynomorph in all the studied samples.
Bisaccate and inaperturate pollen grains were also common. The genera Alisporites, Araucariacites, Ina-perturopollenites, Pinuspollenites, Podocarpidites, Spheripollenites and Vitreisporites, were all identified. Trilete spores of Anapiculatisporites spiniger and Kraeu-selisporites reissingeri, and the monosulcate pollen grains of Cycadopites $\mathrm{sp}$. were common in both boreholes.

\subsection{Palynological assemblages}

Based on changes recorded in the palynological components, three successive palynological assem-blages have been identified in the studied levels of the Upper Triassic and Lower Jurassic (Figs. 4 and 5). The oldest, characteristic of the Rhaetian, was previously recognised in surface sections by Martínez García et al.(1998) and Barrón et al. (2002). The other two assemblages are here described for the first time in Asturias.

\subsubsection{Palynological assemblage 1}

Palynological assemblage 1 (PA1) coincides with the Mudstones and evaporites unit, and includes levels 67 to 112 of the Vilorteo borehole (Fig. 4) and 58 to 97 of the Cantavieyo borehole (Fig. 5). PA1 is characterised by the predominance of Corollina, with Corollina meyeriana (Fig. 6a) the most abundant species. Moderate amounts of Corollina torosa (Fig. 6b), Spheripollenites sp., Ovalipollis pseudoalatus (Fig. 6d) and Tsugaepollenites pseudomassulae (Fig. $7 \mathrm{~g}$ ) pollen grains were found in this assemblage, as well as scarce amounts of Cycadopites sp., Chasmatosporites sp., Granuloperculatipollis rudis, Inaperturopollenites sp., Quadraeculina annellaeformis, Rhaetipollis germanicus (Fig. 6g), Vitreisporites pallidus and Vitreisporites bjuvensis (Fig. 7f). The spores found represented a very low number of specimens of Anapiculatisporites spiniger (Fig. 6c), Cingulitriletes sp., Cyathidites australis, Kraeuselisporites reissingeri (Fig. 6f), Trachysporites fuscus and Uvaesporites argenteaeformis. PA1 is more diverse in the Vilorteo than in the Cantavieyo borehole. In the former, PA1 contains Cingulitriletes sp., C. torosa, K. reissingeri, $Q$. annellaeformis and $\mathrm{V}$. bjuvensis, while in the latter $\mathrm{C}$. australis, Eucommidites troedssonii and $\mathrm{T}$. fuscus were found, along with conspicuous amounts of $T$. pseudomassulae. $T \mathrm{~h} e$ absence of $\mathrm{C}$. torosa in the samples corresponding to PA1 in the Vilorteo borehole is remarkable.

\subsubsection{Palynological assemblage 2}

Palynological assemblage 2 (PA2) is developed within the carbonates of the Solis Member, between 
Table 1

List of palynomorphs identified in the Rhaetian-Hettangian of Asturias

Botanical affinity

General ecology

Aquatic palynomorphs

Cymathiosphaera sp.

Michrystridium sp. Hystrichosphaeridium cf.

langi Wall, 1965 Nannoceratopsis? sp.

Tasmanites sp.

Prasinophyceae

Acritarcha

Dinoflagellata

Dinoflagellata

Prasinophyceae
Brackish-marine

Brackish-marine

Brackish-marine

Marine

Brackish-marine

Miospores

Spores

Acanthotriletes ovalis Nilsson, 1958

Anapiculatisporites spiniger (Leschick 1955) Reinhardt, 1962

Anapiculatisporites sp.

Apiculatisporites leviornatus Levet-Carette, 1965 Calamospora

tener (Leschick 1955) de Jersey, 1962 Carnisporites

megaespiniger Morbey, 1975

Cingulitriletes $\mathrm{sp}$.

Convolutispora microrugulata Schulz, 1967

Cyathidites australis Couper, 1953

Deltoidospora mesozoica (Thiergart 1949) Dörhöfer, 1979

Deltoidospora toralis (Leschick 1955) Lund, 1977 Deltoidospora

sp.

Ischyosporites variegatus (Couper 1958) Schulz, 1967

Kraeuselisporites reissingeri (Harris 1957) Morbey, 1975

Neochomotriletes triangularis (Bolkhovitina) Reinhardt, 1961

Porcellispora longdonensis (Clarke 1965) Scheuring, 1970,

emend. Morbey, 1975

Stereisporites $\mathrm{sp}$.

Todisporites major Couper, 1958

Trachysporites fuscus Nilsson, 1958

Uvaesporites argenteaeformis (Bolchovitina 1953) Schulz, 1967

Pollen grains

Alisporites sp.

Araucariacites australis Cookson, 1947

Cerebropollenites thiergartii Schulz, 1967

Chasmatosporites sp.

Corollina meyeriana (Klaus 1960) Venkatachala

and Góczán, 1964

Corollina torosa (Reissinger 1950) Klaus, 1960 emend. Cornet

and Traverse, 1975

Corollina sp.

Cycadopites sp.

Eucommiidites troedssonii Erdtman, 1948 emend. Hughes, 1961

Ginkgocycadophytus nitidus (Balme 1957) de Jersey, 1962

Granuloperculatipollis rudis Venkatachala and Góczán,

1964 emend. Morbey, 1975

Guthoerlisporites sp.

Inaperturopollenites sp.

Ovalipollis pseudoalatus (Krutzsch 1955) Schuurman, 1976

Perinopollenites elatoides Couper, 1958

Pinuspollenites sp.

Podocarpidites sp.

Quadraeculina anellaeformis Maljavkina, 1949

Rhaetipollis germanicus Schulz, 1967

Spheripollenites $\mathrm{sp}$.

Tsugaepollenites pseudomassulae (Mädler 1964) Morbey, 1975

Undetermined bisaccate pollen grains

Lycophyta

Lycophyta

Lycophyta

Lycophyta

Sphenophyta

Lycophyta

Bryophyta

Pteridophyta (Schizaeaceae) Pteridophyta

(Cyatheaceae/Dicksoniaceae) Pteridophyta

(Cyatheaceae/Dicksoniaceae) Pteridophyta

(Cyatheaceae/Dicksoniaceae) Pteridophyta

(Cyatheaceae/Dicksoniaceae) Pteridophyta

(Schizaeaceae)

Lycophyta

Pteridophyta

Bryophyta (Riellaceae)

Bryophyta (Sphagnaceae)

Pteridophyta (Osmundaceae)

Pteridophyta

Lycophyta (Selaginellaceae)

Pteridospermophyta (Corystospermales)

Coniferophyta (Araucariaceae) unknown

Coniferophyta

Ginkgoales/Cycadales/Bennetitales

Coniferophyta (Cheirolepidiaceae)

Coniferophyta (Cheirolepidiaceae)

Coniferophyta (Cheirolepidiaceae)

Ginkgoales/Cycadales/Bennettitales

Bennettitales/Gnetales Ginkgoales/

Cycadales/Bennettitales

Coniferophyta (Cheirolepidiaceae?)

unknown Coniferophyta Coniferophyta

(Araucariaceae) Cycadophyta

Coniferophyta (Taxodiaceae)

Coniferophyta (Pinaceae)

Coniferophyta (Podocarpaceae)

unknown Coniferophyta Coniferophyta

(Cheirolepidiaceae?) Unknown

Coniferophyta/Bennetitales Unknown

Coniferophyta

Unknown Coniferophyta
Hygrophilous

Hygrophilous

Hygrophilous

Hygrophilous

Hygrophilous

Hygrophilous

Hygrophilous

Hygrophilous

Hygrophilous

Hygrophilous

Hygrophilous

Hygrophilous

Hygrophilous

Hygrophilous

Hygrophilous

Xerophilous

Hygrophilous

Hygrophilous

Hygrophilous

Hygrophilous

Hygrophilous

Xerophilous

Xerophilous

Xerophilous

Xerophilous

Xerophilous

Xerophilous

Xerophilous

Xerophilous

Xerophilous

Xerophilous

Xerophilous

Xerophilous

Xerophilous

Hygrophilous

Xerophilous

Xerophilous

Xerophilous

Xerophilous

Xerophilous

Xerophilous

Xerophilous 
Pollen grains

The table highlights their botanical affinity and general ecology in accordance with the data of Harris (1974), Balme (1995), Batten and Dutta (1997), Hubbard and Boulter (1997), Abbink (1998) and Roghi (2004).

levels 39 to 67 in the Vilorteo borehole and levels 39 to 58 in the Cantavieyo borehole. The palynomorphs of PA1 were poorly preserved. The most common pollen grains, with an abundance of $100 \%$ in some levels (e.g., 62 and 64 of the Vilorteo borehole) belong to Corollina spp. In both boreholes, the presence of spores of Kraeuselisporites reissingeri is remarkable. It is also remarkable in PA2 the presence of Convolutispora microrugulata in the Vilorteo borehole, and Eucommi-dites troedssonii in the Cantavieyo borehole. The occurrence of one species of acritarch (Micrhystridium sp.) and a dinoflagellate cyst (Hystrichosphaeridium cf. langi) as well as a single species of prasinophytes (Cymatiosphaera sp.) in the Vilorteo borehole, indicates a marine to brackish influence.

\subsubsection{Palynological assemblage 3}

Palynological assemblage 3 (PA3) is represented in the upper part of the Solis Member and in the Barzana Member, between levels 1 to 39 in the Vilorteo borehole and levels 3 to 39 in the Cantavieyo borehole. PA3 shows high percentages of Corollina pollen grains, with conspicuous amounts of those of C. torosa. Other gymnospermous pollen grains such as those of Spheripollenites sp., Inaperturopollenites sp., Chasmatosporites sp., Cycadopites sp., Ginkgocycado-phytus nitidus (Fig. 7e), Vitreisporites pallidus, Cere-bropollenites thiergartii (Fig. 7b), Araucariacites australis, Guthoerlisporites sp., Eucommiidites troeds-sonii, Perinopollenites elatoides (Fig. 7d), Alisporites sp., Podocarpidites sp. and Pinuspollenites sp. are present, although scarce. The number of spore species is greater in PA3 than in PA1 or PA2, and included Acanthotriletes ovalis, Anapiculatisporites sp., Apicu-latisporites leviornatus, Calamospora mesozoica, Car-nisporites megaespiniger, Deltoidospora toralis (Fig. 6e), Deltoidospora mesozoica, Ischyosporites variega-tus (Fig. 7a), Kraeuselisporites reissingeri, Neochomo-triletes cf. triangularis, Porcellispora longdonensis, Stereosporites sp. and Todisporites major. Palyno-morph characteristics of marine or brackish environ-ments are poorly represented, as in PA2, and the presence of prasinophytes (Cymatiosphaera sp. and Tasmanites sp.) is weaker. Dinoflagellate cysts, attrib- uted to Nannoceratopsis? sp. (Fig. 7c), genus com-monly cited in Pliensbachian deposits (Stover et al., 1996), were also found. The PA3 of the Vilorteo borehole was characterised by the presence of C. megaespiniger, D. mesozoica, E. troedssonii, Guthoer-lisporites sp., N. cf. triangularis, Tasmanites $\mathrm{sp}$. and the two above mentioned species of acritarchs in PA2. The PA3 of the Cantavieyo borehole shows the species A. ovalis, Calamospora tener, Convolutispora micro-rugulata, Pinuspollenites sp., P. longdonensis, Trachy-sporites fuscus, V. pallidus and Nannoceratopsis? sp.

\subsection{Palynomorph-based biostratigraphy}

Rhaetian and Hettangian biostratigraphy based on palynological studies has never been systematically per-formed on the Iberian platform system. Rhaetian paly-nological assemblages with compositions similar to those of France and northwestern Europe have been recorded in the eastern part of the Spanish Pyrenees (Baudelot and TaugourdeauLantz, 1986; Vachard et al., 1990; Calvet et al., 1993; Fréchengues et al., 1993). However, these assemblages have never been reported in Asturias or in the Basque-Cantabrian Range (Barrón et al., 2001), where assemblages are scarce. A similar situa-tion was reported found in other Lower Jurassic sections of Iberia, where the recorded assemblages show a smaller number of taxa than do those of the rest of Europe (Adloff et al., 1974; Barrón and Goy, 1994; Barrón et al., 1999).

According to Batten and Koppelhus (1996), miospore-based biostratigraphic studies of the Mesozoic have consistently suffered from insufficient reliability with respect to the distribution of taxa. Most appear to be regionally diachronic since their distribution was conditioned by environmental, biogeographical and temporal features. This might be the case for the miospores studied in the two boreholes. However, from the distribution of the main species of palynomorphs in both boreholes, a biozonation that correlates with central and northeastern Europe is here proposed.

\subsubsection{Rhaetipollis germanicus Zone}

In Asturias, the Rhaetipollis germanicus Zone (Figs. 4 and 5) corresponds to the distribution of the index 

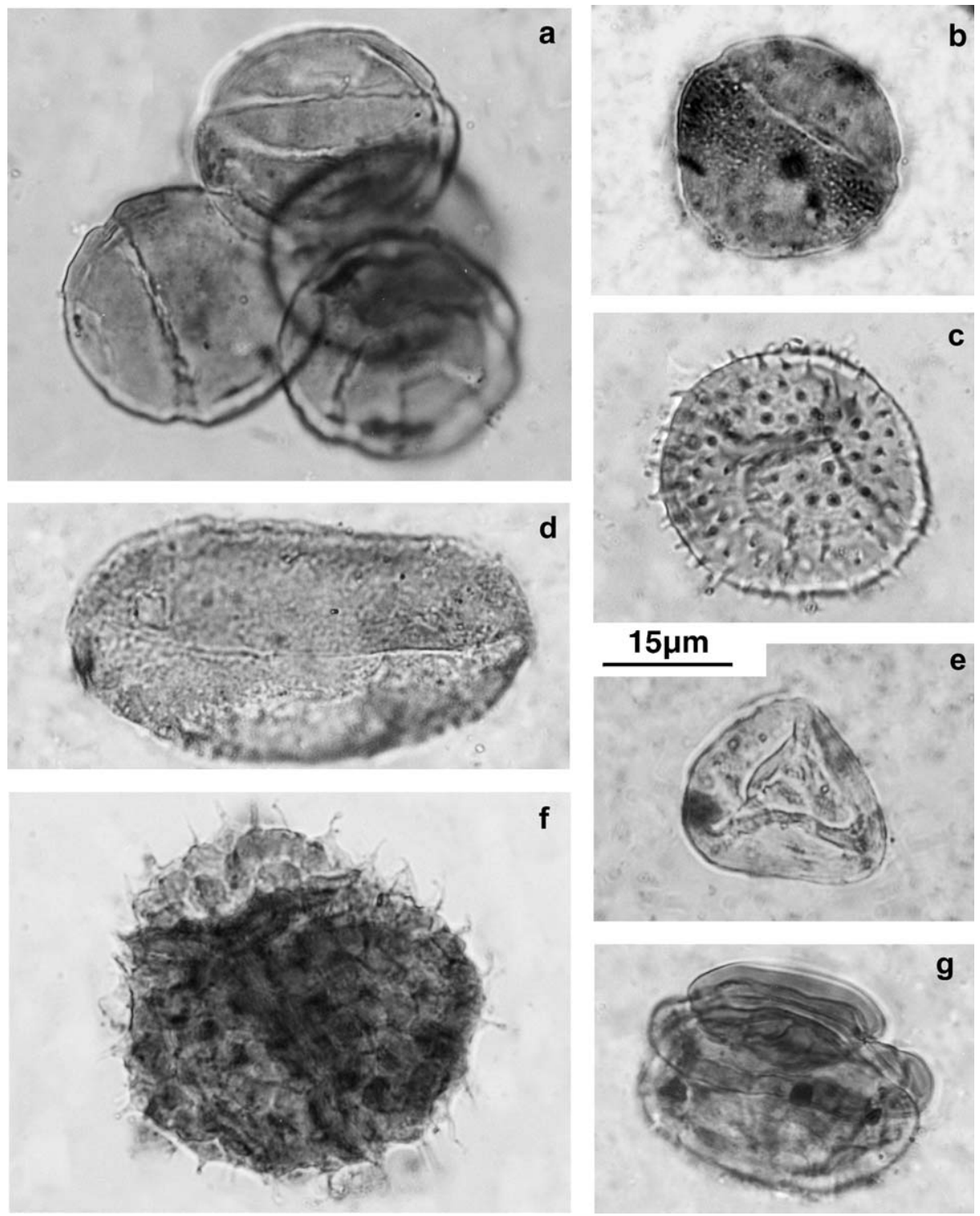

Fig. 6. Spore and pollen types of the Rhaetian and Hettangian of Asturias: (a) Tetrad of Corollina meyeriana (Klaus 1960) Venkatachala and Góczán, 1964, Vilorteo borehole, level 36; (b) Corollina torosa (Reissinger 1950) Klaus, 1960 emend. Cornet and Traverse, 1975, Vilorteo borehole, level 24b; (c) Anapiculatisporites spiniger (Leschick 1955) Reinhardt, 1962, Vilorteo borehole, level 74; (d) Ovalipollis pseudoalatus (Krutzsch 1955) Schuurman, 1976, Vilorteo borehole, level 112; (e) Deltoidospora toralis (Leschick 1955) Lund, 1977, Cantavieyo borehole, level 22; (f) Tetrad of Kraeuselisporites reissingeri (Harris 1957) Morbey, 1975, Vilorteo borehole, level 1; (g) Rhaetipollis germanicus Schulz, 1967, Vilorteo borehole, level 74 . Bar $=15 \mu \mathrm{m}$.

species R. germanicus (Fig. 6g) plus those of Ovalipollis pseudoalatus (Fig. 6d) and Tsugaepollenites pseudo-massulae (Fig. 7g). This zone, which includes the previously mentioned PA1, is developed in the Mud-stones and evaporites unit and appears in the lower part of the Solis Member in both boreholes.

The assemblages of the Rhaetipollis germanicus Zone showed very high percentages of Corollina meyeriana in both boreholes (Fig. 8). This species may be very common in upper Norian-Rhaetian successions of northwestern Europe (Batten and Koppelhus, 1996). Other taxa associated with the Norian-Rhaetian are Granuloperculatipollis rudis and Tsugaepollenites pseudomassulae. First species are common in the uppermost Triassic assemblages of Europe as well as in the Arctic region (Fisher and Bujak, 1975; Pedersen and Lund, 1980). In the St. Audrie's Bay section of the UK, Orbell (1973) 

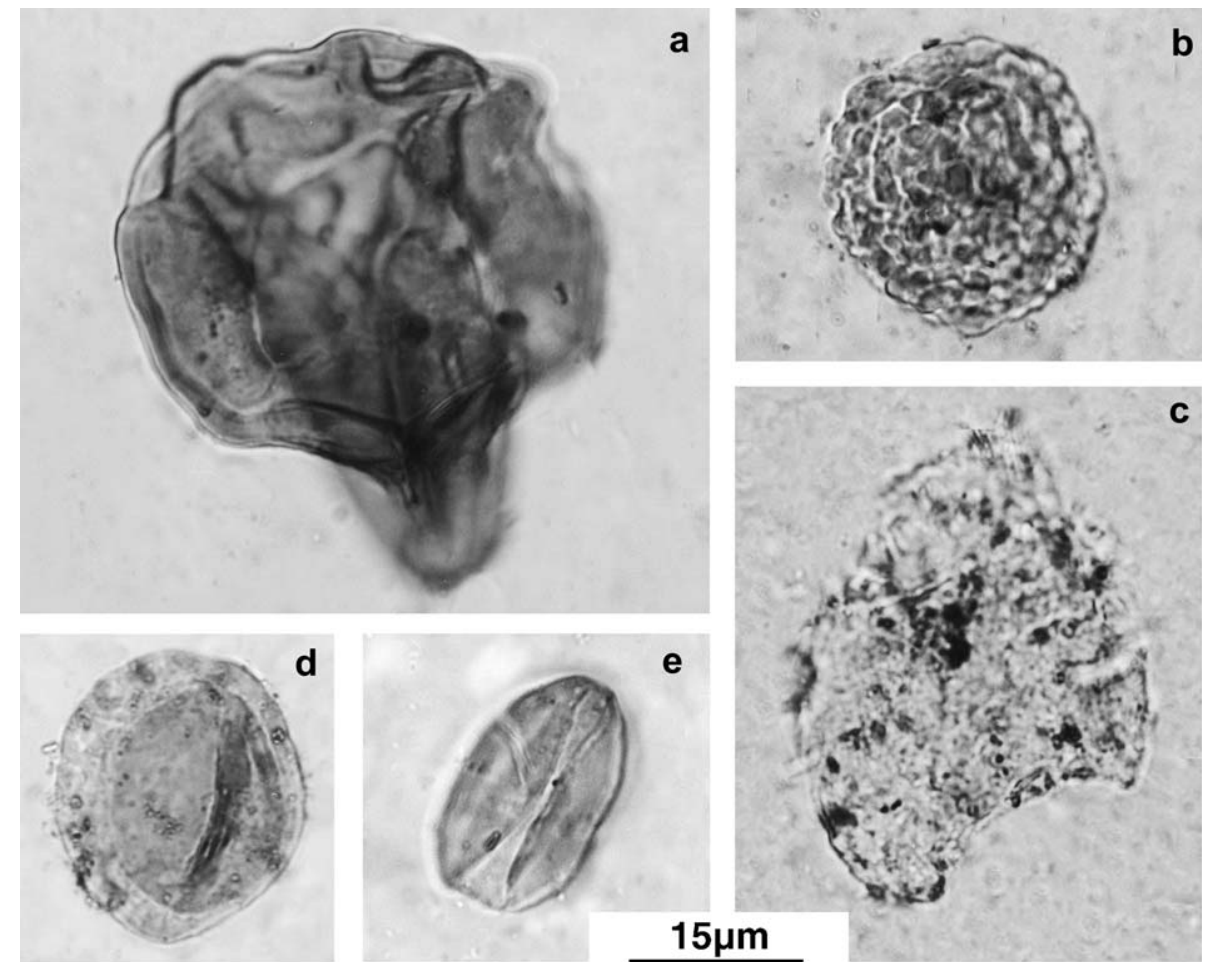

e
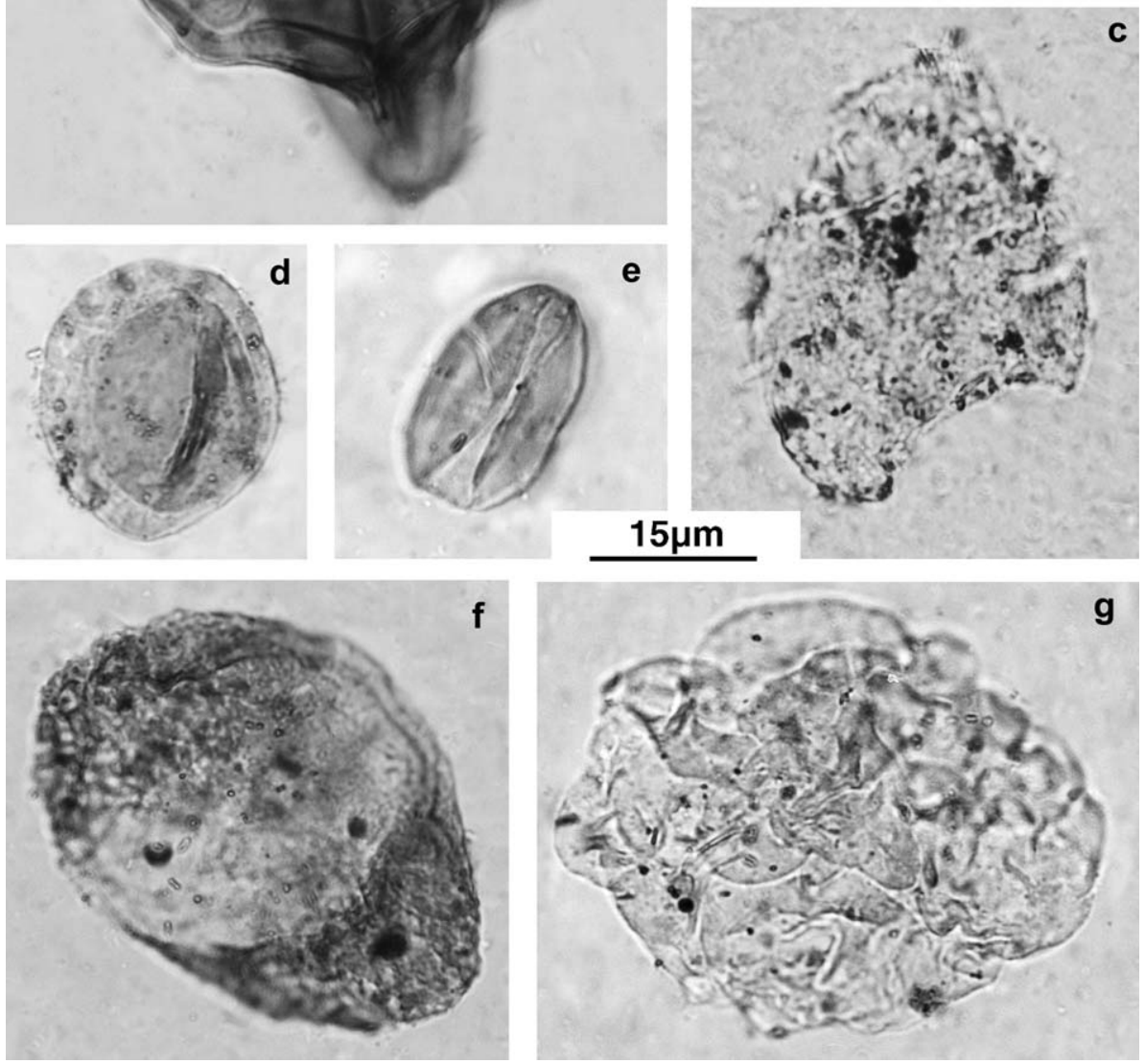

Fig. 7. Dinoflagellate cyst, spore and pollen types of the Rhaetian and Hettangian of Asturias: (a) Ischyosporites variegatus (Couper 1958) Schulz, 1967, Vilorteo borehole, level 36; (b) Cerebropollenites thiergartii Schulz, 1967, Vilorteo borehole, level 30; (c) Nannoceratopsis? sp., Cantavieyo borehole, level 22; (d) Perinopollenites elatoides Couper, 1958, Vilorteo borehole, level 27; (e) Ginkgocycadophytus nitidus (Balme 1957) de Jersey, 1962, Cantavieyo borehole, level 22; (f) Vitreisporites bjuvensis Nilsson, 1958, Vilorteo borehole, level 112; (g) Tsugaepollenites pseudomassulae (Mädler 1964) Morbey, 1975, Vilorteo borehole, level 7.4. Bar = $15 \mu \mathrm{m}$.

mentioned these assemblages in the Rhaetian Grey Marls, where they correspond to the lower part of the Rhaetipollis Zone. In the same section, Hounslow et al. (2004) found this species up to the Westbury Formation, still below the TJB. The second species (T. pseudomassulae) is not common in northern European successions, although it is recorded in the British Rhaetian (Westbury Beds and Cotham Beds; Plate II and Figs. 5 and 7 in Orbell, 1973). Tsugaepollenites pseudomassulae has commonly been found in the
Rhaetian beds of Austria (Morbey and Neves, 1974), in southern France (Peybernes et al., 1988; Fréchen-gues et al., 1992), northern Italy (Cirilli et al., 1993, 1994) and northeastern Spain (Baudelot and Taugour-deau-Lantz, 1986; Vachard et al., 1990; Calvet et al., 1993; Fréchengues et al., 1993), and has also been cited in the Norian beds of Mallorca (Boutet et al., 1982). However, the studied assemblages cannot be assigned to the Norian because of the presence of Anapiculatisporites spiniger (Fig. 6c), Cyathidites 


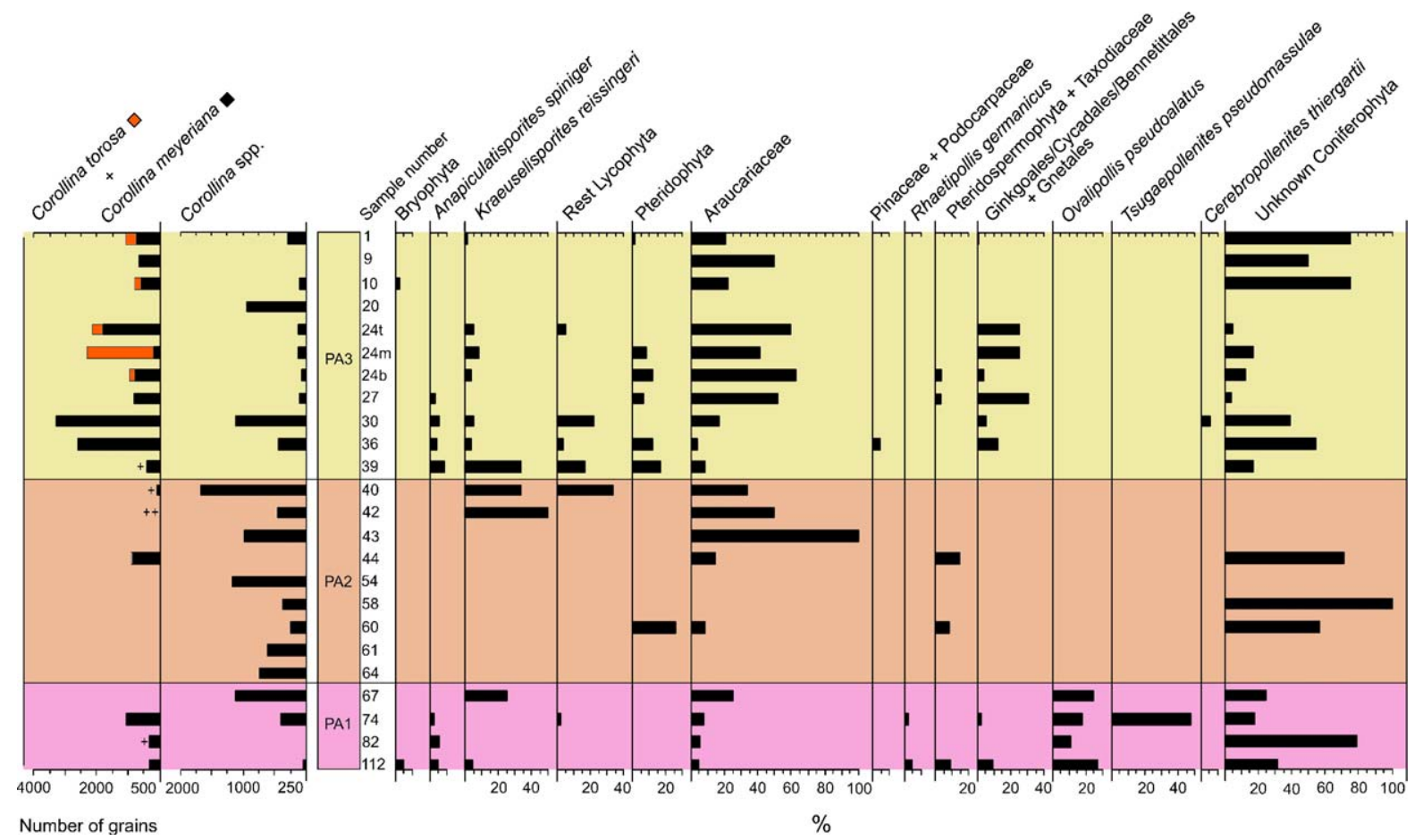

Fig. 8. Pollen diagram of the Vilorteo borehole. ${ }^{+}$A very scarce amount of Corollina torosa. ${ }^{++}$Both species of Corollina are poorly represented. See text for details.

australis and Trachysporites fuscus, whose first appearances are Rhaetian in age (Guy-Ohlson, 1986; Batten and Koppelhus, 1996).

Visscher and Brugman (1981) pointed out a number of species, including Ovalipollis pseudoalatus, Rhaeti-pollis germanicus and Quadraeculina annellaeformis that showed stratigraphic ranges finishing in the Rhaetian. Although the two first species are common in the Rhaetian successions, they are only sporadically cited in the Hettangian beds, as reported by Fisher (1972), Schuurman (1976) and Fisher and Dunay (1981).

The recorded assemblages of the Rhaetipollis germa-nicus Zone may be compared with the Rhaetipollis Zone of southwestern England (Orbell, 1973), with Phase 3 of the characteristic assemblages of the "Grès et Schiste à Avicula contorta" and the "Argiles de Levallois" of Schuurman (1977, 1979), and the Rhaetian assemblages of northwestern Europe. The presence of Tsugaepolle-nites pseudomassulae also allows comparison with the Rhaetian assemblages found in southern Europe (north-eastern Spain, southern France and northern Italy).

\subsubsection{Kraeuselisporites reissingeri Zone}

The Kraeuselisporites reissingeri Zone (Figs. 4 and 5), which is represented in most of the deposits of the Solis Member and the Barzana Member, begins in Asturias with the common and continuous presence of the index species K. reissingeri (Fig. 6f). This appears just after the latest occurrence of Rhaetipollis germanicus and slightly before the latest occurrence of Ovalipollis pseudoalatus and Tsugae-pollenites pseudomassulae. The lower portion nearly coincides with the distribution of PA2, and the upper part includes PA3 from the level of the first occurrence of Ischyosporites variegatus (Fig. 7a). This zone is comparable to the Heliosporites Zone of Orbell (1973).

The lower part of the Kraeuselisporites reissingeri Zone, which corresponds to PA2, shows high percen-tages of poorly preserved miospores and a very low diversity of taxa. Only 11 taxa could be identified in the Vilorteo borehole and 9 in the Cantavieyo borehole. Despite the poor preservation of the palynomorphs, the Rhaetian-Hettangian species Convolutispora microru-gulata, Hystrichosphaeridium cf. langi were identified. The appearance of Ovalipollis pseudoalatus in both boreholes (level 68 of the Vilorteo borehole and level 54 of the Cantavieyo borehole) also indicates a Rhaetian-Hettangian age. Given the occurrence of Tsugaepolle-nites pseudomassulae at level 54 of the Cantavieyo borehole, a Rhaetian age for the lower part of the Solis Member can be concluded. 
The upper part of the Kraeuselisporites reissingeri Zone, which corresponds to PA3, includes those levels located above the first occurrence of Ischyosporites variegatus. The zone is characterised by conspicuous amounts of Corollina torosa and Jurassic taxa such as $\mathrm{I}$. variegatus and Cerebropollenites thiergartii, as well as the disappearance of Triassic taxa such as Granuloperculatipollis rudis, Ovalipollis pseudoalatus, Rhaetipollis germanicus and Tsugaepollenites pseudomassulae. The most abundant spore type is that of $\mathrm{K}$. reissingeri, which was recorded at almost all the studied levels of the upper part of the $\mathrm{K}$. reissingeri Zone in the successions of both drillholes. This species shows a large stratigraphic range throughout the Early Jurassic to the Aalenian (Guy-Ohlson, 1986; Batten and Koppelhus, 1996).

Samples from both boreholes showed a high proportion of Corollina torosa (Fig. 6b) in the upper part of the Kraeuselisporites reissingeri Zone (Figs. 4 and 5). This species was rarely recorded in the Rhaetipollis germanicus Zone or the lower part of the K. reissingeri Zone in the Vilorteo borehole. Neverthe-less, Corollina meyeriana (Fig. 6a) was the most abundant species in the upper part of the $\mathrm{K}$. reissingeri Zone in both boreholes, as in the Rhaetipollis germanicus Zone (Figs. 4 and 5). Corollina torosa ranges from the Late Carnian throughout the Mesozoic (Schultz and Heunisch, 2005). This species is the most abundant taxon in some of the Rhaetian assemblages of Scania in Sweden (Guy-Ohlson, 1981), the Canadian Arctic Archipelago (Fisher, 1979), and the Vienna Basin of Austria (Planderová, 1980). It is also seen in several Hettangian sections, such as the Figeac-Capdenac in France (Grignac and Taugourdeau-Lantz, 1982). How-ever, C. meyeriana shows a more limited stratigraphic range from the Norian to Lower Jurassic. This last species numerically dominates the Rhaetian of Saint-Chinian in the Bas-Languedoc, France (Fréchengues et al., 1992), Monte Cetona in the northern Apennines (Cirilli et al., 1994), BacGrillera in Catalonia (north-eastern Spain) (Vachard et al., 1990) and the Hettangian of the Barnstone railway cutting in Nottinghamshire, England (Fisher, 1972).

The finding of Ischyosporites variegatus (Fig. 7a) in level 39 of the Vilorteo borehole and level 32 of the Cantavieyo borehole confirms a Hettangian age from these levels up to the top of both successions. This species is recorded from the uppermost Pliensbachian in northwestern Europe (Batten and Koppelhus, 1996) but this range does not match the record for southern Europe (Srivastava, 1987). Ischyosporites variegatus was identified in the Hettangian of Figeac-Capdenac in Quercy, France (Grignac and Taugourdeau-Lantz,
1982), in the Hettangian-Sinemurian of the Lusitanian Basin in Portugal (Adloff et al., 1974), and in the Lower Jurassic of the Vicentine Alps in Italy (ClementWesterhof et al., 1974). Similarly, Corollina meyeriana (Fig. 6a) seems to have a longer biostratigraphic range in southern Europe and Asia Minor than in northwestern Europe. This species was identified in the Hettangian-Sinemurian of the Lusitanian basin in Portugal (Adloff et al., 1974) and in the PliensbachianToarcian of Israel (Conway et al., 1990). Another typical Early Jurassic element was Cerebropollenites thiergartii (Fig. 7b), which in northwestern Europe ranges from the Hettan-gian to the Pliensbachian (Batten and Koppelhus, 1996). These species, identified in levels 30 and 1 of the Vilorteo borehole and level 3 of the Cantavieyo borehole, have never before been mentioned in the Hettangian beds of Spain.

The species Porcellispora longdonensis was only recorded in the upper part of the Kraeuselisporites reissingeri Zone in the Cantavieyo borehole. Spores of this species are found throughout the Triassic in northwestern Europe, but in southern Europe, they have also been found in Lower Jurassic deposits. For example, P. longdonensis has been recorded in the Lower Jurassic of the Vicentinian Alps in Italy (Clement-Westerhof et al., 1974), in the Hettangian beds of the Villaviciosa region of Asturias (Barrón et al., 2002) and in the Hettangian of northern Germany (Schultz and Heunisch, 2005).

In the upper part of the Kraeuselisporites reissingeri Zone of the Vilorteo borehole, several taxa such as Carnisporites megaespiniger, Deltoidospora meso-zoica, Guthoerlisporites sp., Neochomotriletes cf. triangularis and Perinopollenites elatoides (Fig. 7d) were identified which were not present in the Canta-vieyo borehole. These taxa range from the Late Triassic to Jurassic (Morbey, 1975; Schuurman, 1977; Pedersen and Lund, 1980; Batten and Koppelhus, 1996). In the Cantavieyo borehole, the upper part of the K. reissingeri Zone is characterised by Acanthotriletes ovalis, Calamospora tener, Convolutispora microrugulata, Porcellispora longdonensis and Trachysporites fuscus, which shows a similar range to the taxa mentioned for the Vilorteo borehole.

The presence of Kraeuselisporites reissingeri (Fig. 6f), as well as other Rhaetian-Hettangian taxa such as Anapiculatisporites spiniger (Fig. 6c), Apiculatisporites leviornatus, Corollina meyeriana and Deltoidospora toralis (Fig. 6e), may relate the upper part of $K$. reissingeri Zone to the Heliosporites Zone of south-western England (Orbell, 1973) and with Schuurman's Phase 5 (1977, 1979). 
In general, the observed assemblages are comparable to other Lower Jurassic assemblages from Luxembourg and southern Europe, as are those of the Lusitanian Basin and southern France (Adloff et al., 1974; Adloff and Doubinguer, 1982; Grignac and Taugourdeau-Lantz, 1982).

\section{Discussion and conclusions}

\subsection{Chronostratigraphic remarks}

Biochronostratigraphic analysis of the identified assemblages allowed the uppermost $30 \mathrm{~m}$ (at least) of the Mudstones and evaporites unit to be dated as Upper Triassic (Rhaetian), based on the presence of palyno-morphs characteristic of the Rhaetipollis germanicus Zone. The lowermost part of the Solis Member is also attributed to the Upper Triassic (Rhaetian), based on taxa characteristic of the upper part of the Rhaetipollis germanicus Zone. The presence of the typically Triassic species Ovalipollis pseudoalatus and Tsugaepollenites pseudomassulae (Morbey and Neves, 1974; Visscher and Brugman, 1981; Fowell and Olsen, 1993; Houn-slow et al., 2004) up to level 54 of the Cantavieyo borehole indicates a Rhaetian age for the lower part of the well bedded carbonates of the Solis Member (Fig. 5).

Levels 68 to 39 in the Vilorteo borehole and 58 to 39 in the Cantavieyo borehole cannot be confidently assigned to the Rhaetian or to the Hettangian due to the absence of representative palynomorphs of these ages. This part of the section is referred to as the Rhaetian-Hettangian transition.

The presence of Ischyosporites variegatus from level 39 of the Vilorteo borehole suggests that the carbonates of the Solis Member are Jurassic in age, at least from this level. Some of the sampled levels in the upper part of the Solis Member and in the Barzana Member contained I. variegatus and Cerebropollenites thiergartii, which can be attributed to the Hettangian. In addition, the finding of a specimen of Caloceras pirondii by Llopis (1961)(studied by Dubar et al., 1963) in a fossiliferous level attributed to the uppermost $12 \mathrm{~m}$ of the Solis Member in a surface outcrop, confirms a lower Hettangian age for these levels.

Detailed analysis of the deposits intersected in the Vilorteo and Cantavieyo borehole, and the Barzana and Fabares sections (Barrón et al., 2002) showed remark-able similarities with some of the most significant TJB sections in central and northwestern Europe. In particular, the Asturian sections can reasonably be correlated with that of St. Audrie's Bay (Orbell, 1973; Mayal, 1981; Hallam, 1990; Hesselbo et al., 2002, 2004;
Hounslow et al., 2004), which was proposed as the Global Boundary Stratotype Section and Point (GSSP) for the base of the Jurassic System by Warrington et al.(1994). In Asturias, the palynomorph assemblages found in the Mudstones and evaporites unit are quite similar to the assemblages described for the Westbury Formation. In addition, the assemblages found in the lower portion of the Solis Member include many elements common to the assemblages of the Lilstock Formation, and in particular those of the palynomorph assemblages described for the Cotham Member (Orbell, 1973; Hounslow et al., 2004).

\subsection{Palaeoenvironmental features}

Spores and pollen grains are excellent sources of information on terrestrial palaeoecological and palaeo-climatic conditions. Nevertheless, palaeoecological reconstructions of Mesozoic environments based on palynological studies are complex; the plants that existed during this Era usually have no modern descendants. This generally prevents actualistic studies from being undertaken.

Late Triassic and Early Jurassic floras were fairly abundant and widely distributed in the Northern Hemisphere, but rather scarce and unevenly distributed in the rest of the world (Ash, 1986). These floras were composed of lycopods, horsetails, ferns, seed ferns, cycads, Bennettitales, Ginkgoales, Czekanowskiales and conifers. The data provided by the megafloras show conspicuous changes at the TJB, which were evident from the study of the assemblages of the Lepidopteris ottois and Thaumatopteris schenki zones (Harris, 1931; Pedersen and Lund, 1980) that respectively characterise the Rhaetian and the Hettangian of Northern Europe. The replacement of the northern floras seems to be related to an increase in temperature. This is confirmed by a change of taxonomic composition, as well as changes in leaf physiognomy (McElwain et al., 1999) and the abun-dance of leaf stomata (Retallack, 2001). Palynomorphs also show a significant change along the TJB in the Northern Hemisphere (Batten and Koppelhus, 1996). However, this change seems to be more gradual than that of the megaflora. The first changes of the Late Triassic palynofloras were recorded at the Norian, coinciding with the first appearance of Corollina pollen grains (Visscher and Brugman, 1981) and the loss of diversity among terrestrial vertebrates and marine invertebrates (Weems, 1992; Tanner et al., 2004).

To detect floral turnover in response to palaeoenviron-mental changes, a quantitative analysis was performed. Miospores were organised into two groups based on their 
main ecological preferences, mainly the water needs of the different plants and their adaptability to more or less dry environments (Table 1). In addition, pollen diagrams for both boreholes have been performed (Figs. 8 and 9).

In both pollen diagrams, very high percentages of the genus Corollina have been recorded, making these pollen grains clearly dominant in the observed assemblages. The over-representation of Corollina is surely owed to anemophilous cheirolepidiaceous plants which produced large amounts of pollen. The genus Corollina, produced by extinct voltzialean conifers of the Cheirolepidiaceae family (Jarzen and Nichols, 1996), was usual in many ecosystems of the Latest Triassic and Early Jurassic as reflects their predominance in a large number of palynological assemblages during this interval in both hemispheres. In several locations, e.g., the Richmond Basin, the TJB is marked by assemblages dominated by this genus (Fowell et al., 1994). In general, Corollina meyeriana dominated over Corollina torosa in the studied assemblages. However, C. torosa, which was scarcely seen in the PA1 of the Vilorteo borehole (level 82), became preponderant in several levels of PA3 (level 24 of the Vilorteo borehole and levels 15 and 28 of the Cantavieyo borehole).

To present a more understandable picture of the palynological information recorded in Asturias, the percentages of Corollina have been represented sepa-rately from the other pollen grains in both diagrams (Figs. 8 and 9). Comparison of the diagrams obtained from the two boreholes show conspicuous differences.
Large amounts of Corollina spp. can be recognised in the PA1 of the Cantavieyo borehole, while in the same assemblage in the Vilorteo borehole this taxon is only well represented in the upper part of PA1. In addition, the Cantavieyo borehole shows an important represen-tation of bisaccate pollen grains of the families Pinaceae and Podocarpaceae, as well as Porcellispora long-donensis and scarce Sphenophyta, which are poorly represented or absent in the Vilorteo borehole. In contrast, unknown Coniferophyta, mainly due to the high amounts of Spheripollenites sp., are abundant in the samples from the Vilorteo borehole, whereas they are much less significant in the Cantavieyo borehole. In both boreholes the Triassic species Ovalipollis pseu-doalatus, Tsugaepollenites pseudomassulae and Rhae-tipollis germanicus present noticeable percentages in PA1, disappearing in PA2 as a consequence of the floral change that became at the TJB. These species seem to have been replaced in PA3 by other related to Cycadales, Ginkgoales, Bennettitales and Gnetales as Ginkgocyca-dophytus nitidus, Chasmatosporites sp., Cycadopites sp., Eucommiidites troedssonii and the pollen of the unknown Coniferophyta Cerebropollenites thiergartii.

Although the ecology of the conifers which produced Corollina has long been a subject of debate, arid environmental conditions can be inferred from the predominant presence of these pollen grains in all studied samples. In general, Cheirolepidiaceae seem to be drought resistant, thermophilous shrubs and trees that required at least a subtropical climate (Francis, 1983; Vakhrameev, 1991). Some species of this family were

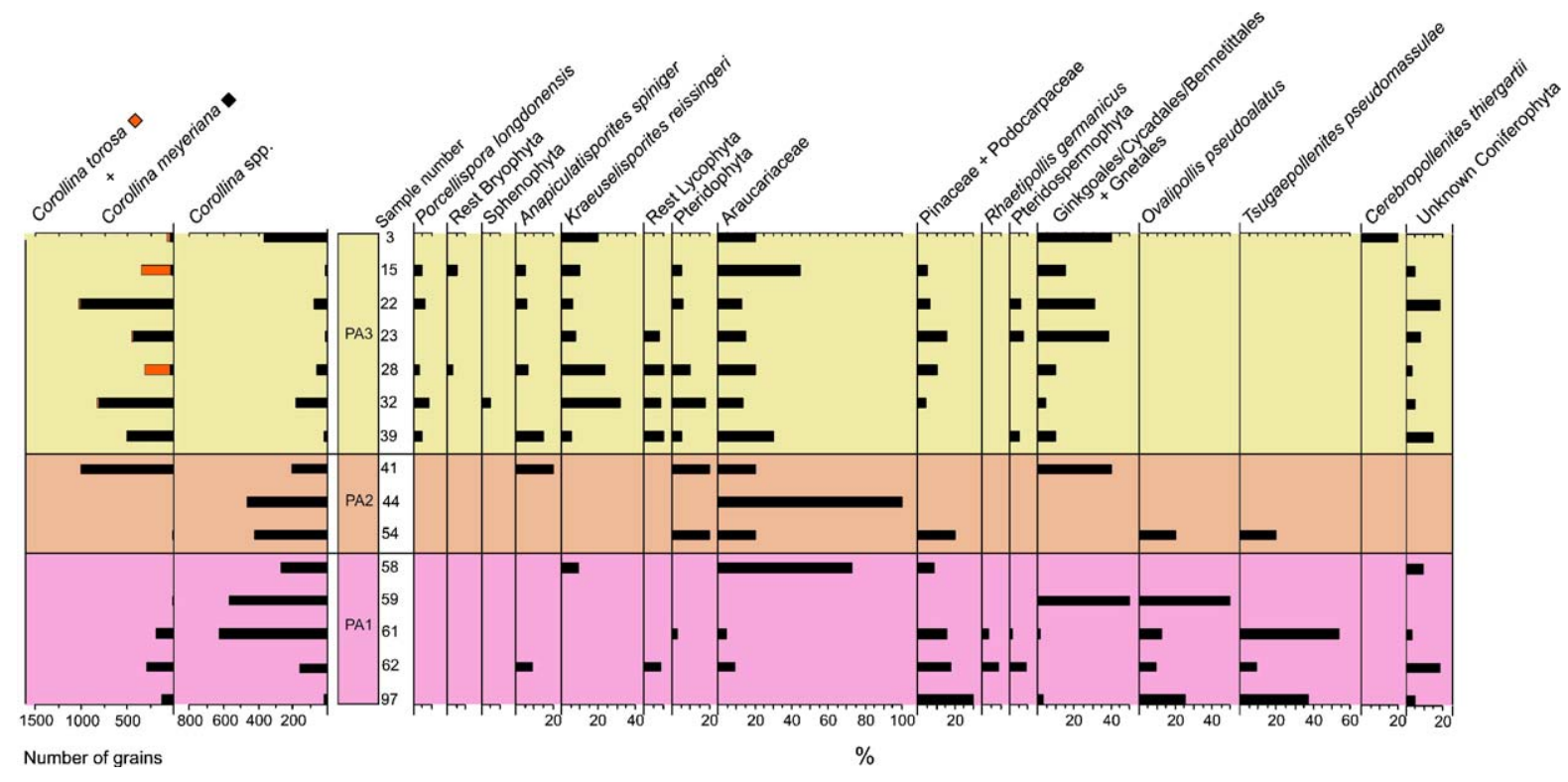

Fig. 9. Pollen diagram of the Cantavieyo borehole. See text for details. 
probably coastal plants (Alvin, 1982; Watson, 1988). These arid conditions agree with the palaeogeographical location of the northern Iberian Peninsula during the Late Triassic and Early Jurassic since it was between paleolatitude $25^{\circ}$ and $30^{\circ}$ (Gaetani et al., 2000; Thierry, 2000). According to Rees et al. (2000), the palaeocli-matic conditions of Iberia during the Early Jurassic were desert-like, which agrees with the deposition of thick piles of evaporites during Late Triassic and Early Jurassic south of Asturias, in most of Spain.

Disregarding Corollina, both pollen diagrams are characterized by anemophilous alete and monosulcate pollen grains and by spores of Lycophyta. Vilorteo and Cantavieyo boreholes show high percentages of alete pollen grains related to the family Araucariaceae. These percentages are more conspicuous in PA2 and PA3. Pollen grains of Araucariaceae can be correlated with a warm climate without large seasonal amplitudes and may be indicative of coastal environments (Mohr, 1989; Abbink, 1998). Then, the high presence of pollen of Corollina and Araucariaceae seems to indicate forestal plant communities that grew near the coasts and were possibly affected by droughts due to both climate and soils with high salt content. Supporting this assumption, several authors stated that the presence of large numbers of Spheripollenites together with large numbers of Corollina, sustain a more steady development of annual dry seasons (Alvin, 1982; Mohr, 1989).

Although climatic conditions were arid, the multivariate statistical studies performed by Hubbard and Boulter (1997) on the TJB palynological assemblages of the Northern Hemisphere, suggest that the two cited species of Corollina had different ecological needs. Corollina meyeriana was related to colder flora than Corollina torosa. Considering only the data provided by this genus, the larger amounts of Corollina in PA1 and PA2 could indicate colder climatic conditions than in PA3 in which C. torosa predominates in a few levels. Warmer climatic conditions during the Hettangian agree with palaeoecological and sedimentological data from Western Europe and Greenland (Hubbard and Boulter, 2000). Rapid warming during the TJB has been pointed out by many authors in several areas, based on palaeobotanical evidences (Fowell and Olsen, 1993; McElwain et al., 1999; Hesselbo et al., 2002; Jenkyns, 2003).

We have not found a satisfactory explanation for the early appearance of Corollina torosa in PA1 in the Vilorteo borehole and the lack of record of this species in the Cantavieyo borehole until the beginning of PA3. However, C. torosa is always present in percentages lower than 5\% in PA1 and PA2 in the Vilorteo borehole. Percentages above $5 \%$ are recorded in both boreholes only in PA3 (Figs. 4-5, and 8-9).

Although the spores of vascular cryptogamma are present along the two boreholes, they show a high diversity and abundance in PA3. Spores related to Lycophyta are the most abundant spores in both boreholes being Kraeuselisporites reissingeri and Anapiculatisporites spiniger the most conspicuous species. Bryophyta are well represented in the Canta-vieyo borehole being scarce in the Vilorteo borehole. Sphenophyta are only represented in the Cantavieyo borehole, whereas Pteridophyta exhibits remarkable percentages in both boreholes, although are not present in PA1 of the Vilorteo borehole.

Generally, vascular cryptogamma need a humid environment for their reproduction. Nevertheless, some of them grew under much drier and stressed conditions especially during the Mesozoic (Abbink, 1998; Van Konijnenburg-Van Cittert, 2002). This is the case of several Bryophyta and Pteridophyta which grew in dry places and could withstand long periods of drought. Concretely, the presence of Porcellispora longdonensis in PA3 in the Cantavieyo borehole is indicative of seasonal droughts that provoked the desiccation of wet areas (Reinhardh and Ricken, 2000). Likewise, the occurrence of Cyathidites australis and Deltoidospora spp., would suggest the existence of high-stress environments. On the contrary, the spores of Sphenophyta, Lycophyta and some Bryophyta (Stereo-sporites sp.) and Pteridophyta (Convolutispora micro-rugulata, Ischyosporites variegatus and Todisporites major) indicate plants that require wet habitats. These habitats could be coastal swamps or ponds with humid soils, although in the Late Triassic and Early Jurassic of the Asturian region, they developed under general arid conditions.

No evidences of local environmental variations that could explain the changes recorded in the successive palynological assemblages have been observed in the studied area. The boundaries between the three different palynological assemblages are recorded within the carbonates of the Solis Member, which were deposited in shallow platform to intertidal and supratidal environments. The environmental conditions indicated by the palynological assemblages fully agree with the coastal subtropical environments indicated by the sediments. The absence of significant changes in the depositional settings does not support that local environmental modifications were the unique respon-sible for palaeoecological changes and subsequent appearance and disappearance of taxa. Regional data 


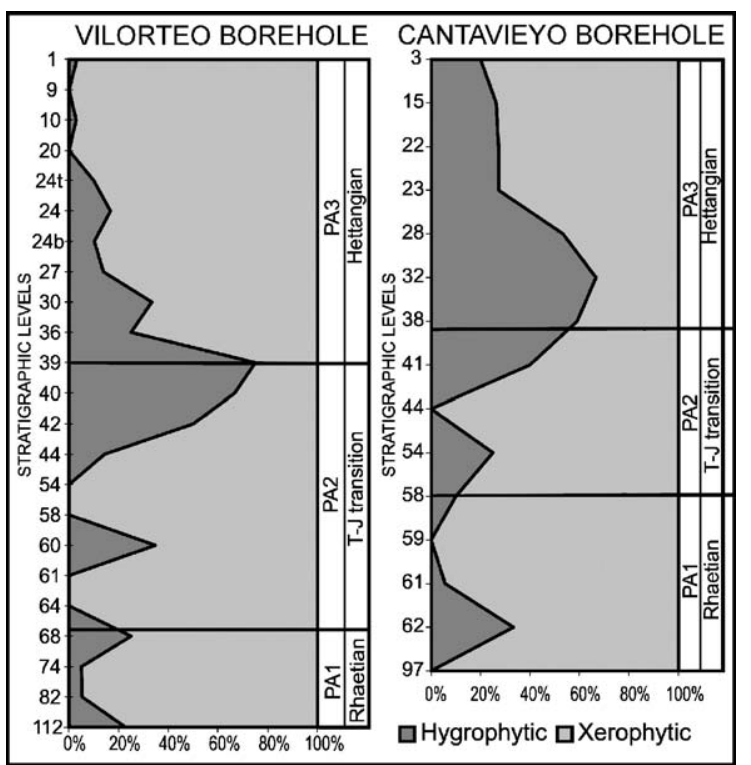

Fig. 10. Relative abundance of hygrophilous and xerophilous taxa (disregarding Corollina pollen grains). The diagrams show an increase in hygrophilous taxa at the beginning of PA3 in both boreholes.

indicate that the stratigraphic equivalents of the Solis carbonate platform southwards are evaporitic deposits similar to the sediments constituting the Mudstones and evaporites unit and the Barzana Member (Gómez and Goy, 2005). In the transition between the carbonate platform and the continental evaporitic facies, coastal swamps or ponds with humid soils constituted an adequate habitat for vascular crypto-gamma. In the evaporitic basin located southward of the carbonate platform (Iberian Ranges, Fig. 2) dominated by arid climates, Cheirolepidiaceae related to saline soils could form forestal communities.

In both boreholes disregarding Corollina, $\mathrm{t} \mathrm{h}$ e palynomorph assemblages showed a predominance of xerophilous taxa related to conifers in PA1 and the lower part of PA2 (Fig. 11). A remarkably greater proportion of hygrophilous taxa appeared in the upper part of PA2 (level 42 of the Vilorteo borehole and 41 of the Cantavieyo borehole), indicated by the increase in proportions of Kraeuselisporites reissin-geri and Anapiculatisporites spiniger. The peak in the abundance of these taxa coincided with the first appearance of Ischyosporites variegatus. From level 39 in the Vilorteo borehole and 23 in the Cantavieyo borehole, a new reduction in hygrophilous taxa has been observed. Finally, the upper part of PA3 is characterised by the new predominance of xerophi-lous taxa, represented by alete and sulcate pollen

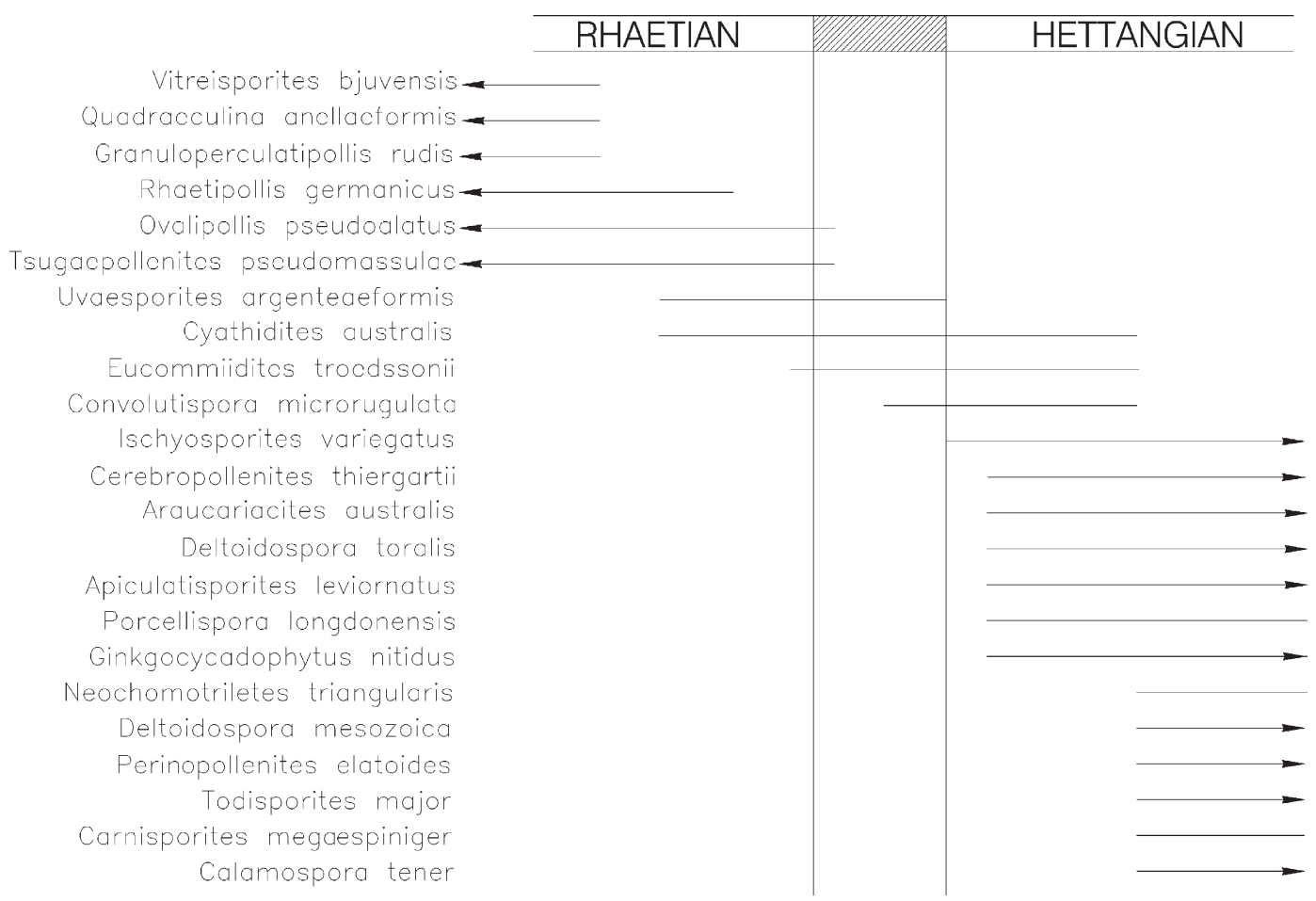

Fig. 11. Composite range chart summarising the selected species found in Asturias that do not surpass the Rhaetian-Hettangian boundary, and those that make their first appearance in the Hettangian. The long-ranging species and the commonly known taxa that surpass the boundary have been excluded. 
grains. This increase in the proportion of palynomorphs corresponding to hygrophilous plants suggests a climate change towards more humid conditions in Asturias at the beginning of the Jurassic (Fig. 10). This change to a short, humid event sparked the renewal of the flora, indicated by the increased proportion of hygrophilous plants and the remarkable recovery of conifers and vascular cryptogamma. The predominance once again of xerophilous species later on in the Hettangian is indicative of a recovery of arid climatic conditions.

The TJB was located within the carbonates of the Solis Member in both boreholes, and organised into normal metric-scale shallowing-upward sequences. These do not support the occurrence of marked sea-level fluctuations at the Triassic-Jurassic transition in Asturias. Such events were originally proposed by some authors as a possible cause of the end-Triassic mass extinction (Hallam, 1989, 1995, 1998; Hallam and Wingall, 1999, 2000). The presence of very scarce dinoflagellate cysts, acritarchs and prasinophytes in PA2 and PA3 might be interpreted as an influence of brackish or marine environments, as corroborated by the sedimentary environments. The appearance of acantho-morph acritarchs of genus Micrhystridium and chorate dinoflagellate cysts of genus Hystrichosphaeridium and in PA2 of the Vilorteo borehole are indicative of an inshore, partly enclosed environment (Warrington and Harland, 1975).

During the Rhaetian, coniferous forests developed in Asturias. Near the TJB, they underwent important impoverishment due to the extinction of mainly Triassic taxa such as Rhaetipollis germanicus, Granuloperculatipollis rudis, Ovalipollis pseudoalatus and Tsugaepollenites pseudomassulae. Plant communities were reduced to cheirolepidiaceous formations with under-growth containing scarce lycophites and ferns. As indicated by the amounts of vascular cryptogamma spores, an increase of wet areas was appreciated at the beginning of the Hettangian. Later, dry conditions returned, and coniferous forests appeared with Cheir-olepidiaceae, Araucariaceae, Pinaceae and Ginkgoales/Cycadales/ Bennettitales.

Distribution of select-recorded species is summa-rized in Fig. 11. The Triassic-Jurassic turnover and the later recovery of new species in the Early Jurassic are well marked in Asturias. Seven palynomorph species failed to surpass the top of the Rhaetipollis germanicus Zone of the Rhaetian, six were recorded in the Rhaetian-Hettangian transition, and 22 taxa in the Hettangian, marking the outstanding phase of recovery indicated by the studied palynomorphs.

\section{Acknowledgements}

This research work was financed by projects CGL2005-01765/BTE of the Ministerio de Educación y Ciencia and BTE 2001-1924 from the Ministerio de Ciencia y Tecnología. We wish to thank S. Cirilli (University of Perugia, Italy) and the anonymous editor and referee who provided useful criticism and valuable suggestions for the improvement of the manuscript. We thank the La Camocha Mine for permission to study and sample the Vilorteo and Cantavieyo boreholes. We also thank Dr. C. Herrero for her help in field work, and Dr. C. Diéguez for her constructive comments on this manuscript. We also thank A. Burton for his language review. This paper is a contribution to the International Geological Correlation Program Project 458 (Triassic-Jurassic boundary events).

\section{References}

Abbink, O.A., 1998. Palynological investigations in the Jurassic of the North Sea region. Lab. Palaeobot. Palynol. Contrib. Ser. 8, 1-191.

Adloff, M.C., Doubinguer, J., 1982. Étude palynologique du Rhétien et de l'Hettangien de cinq sondages situés dans les environs de Mersch (Luxembourg). Bull. Inform. Geol. Basin Paris 19, 9-20.

Adloff, M.C., Doubinguer, J., Palain, C., 1974. Contribution à la palynologie du Trias et du Lias inférieur de Portugal, "Grès de Silves" du Nord Tage. Comm. Serv. Geol. Portugal 58, 91-144.

Alvin, K.L., 1982. Cheirolepidiaceae: biology, structure and palaeoecology. Rev. Palaeobot. Palynol. 37, 71-98.

Ash, S., 1986. Fossil plants and the Triassic-Jurassic boundary. In: Pandian, K. (Ed.), The Beginning of the Age of Dinosaurs. Cambridge Univ. Press, New York, pp. 21-30.

Aurell, M., Meléndez, G., Bádenas, B., 2002. East Iberian basins. In: Gibbons, W., Moreno, T. (Eds.), The Geology of Spain. Geological Society, London, pp. 223-229.

Aurell, M., Robles, S., Bádenas, B., Rosales, I., Quesada, S., Meléndez, G., García-Ramos, J.C., 2003. Transgressive-regressive cycles and Jurassic palaeogeography of northeast Iberia. Sediment. Geol. 162, 239-271.

Balme, B.E., 1995. Fossil in situ spores and pollen grains: an annotated catalogue. Rev. Palaeobot. Palynol. 87, 81-323.

Barrón, E., Goy, A., 1994. Caracterización palinológica del tránsito Triásico/Jurásico en la región de Sigüenza: II. Coloquio de Estratigrafía del Pérmico y Triásico de España, Cuenca, Abstracts, p. 13.

Barrón, E., Comas-Rengifo, M.J., Trincão, P., 1999. Estudio palinológico del tránsito Pliensbachiense/Toarciense en la Rambla del Salto (Sierra Palomera, Teruel, España). Cuad. Geol. Ibérica 25, 171-187.

Barrón, E., Gómez, J.J., Goy, A., 2001. Dataciones con palinomorfos en los materiales del tránsito Triásico-Jurásico de Poza de la Sal (Burgos). Publ. Sem. Paleontol. Zaragoza 5.1, 46-55.

Barrón, E., Gómez, J.J., Goy, A., 2002. Los materiales del tránsito Triásico-Jurásico en la región de Villaviciosa (Asturias, España). Caracterización palinológica. Geogaceta 31, 197-200. 
Batten, D.J., Dutta, R.J., 1997. Ultrastructure of exine of gymnospermous pollen grains from Jurassic and basal Cretaceous deposits in Northwest Europe and implications for botanical relationships. Rev. Palaeobot. Palynol. 99, 25-54.

Batten, D.J., Koppelhus, E.B., 1996. Chapter 20D. Biostratigraphic significance of uppermost Triassic and Jurassic miospores in Northwest Europe. In: Jansonius, J., McGregor, D.C. (Eds.), Palynology: Principles and Applications. Am. Assoc. Stratigr. Palynol. Found., vol. 2, pp. 795-806.

Baudelot, S., Taugourdeau-Lantz, J., 1986. Découverte d'une microflore dans les Pyrénées Catalanes attribuable au Norien-Rhétien. Rev. Paléobiol. 5, 5-9.

Beerling, D., 2002. $\mathrm{CO}_{2}$ and the end-Triassic mass extinction. Nature 415, 386-387.

Boutet, Cl., Rangheard, Y., Rosenthal, P., Visscher, H., Durand-Delga, M., 1982. Découverte d'une microflore d'âge Norien dans la Sierra Norte de Majorque (Baléares, Espagne). C. R. Acad. Sci. Paris 294, 1267-1270.

Calvet, F., Solé de Porta, N., Salvany, J.M., 1993. Cronoestratigrafía (Palinología) del Triásico Sudpirenaico y del Pirineo VascoCantábrico. Acta Geol. Hisp. 28, 33-48.

Cirilli, S., Bucéfalo-Palliani, R., Pontini, M.R., 1993. Palynostratigraphy and palynofacies of the Late Triassic $R$. contorta facies in the Northern Apennines: I. The La Spezia Formation. Rev. Paléobiol. 12, 179-192.

Cirilli, S., Bucéfalo-Palliani, R., Pontini, M.R., 1994. Palynostratigraphy and palynofacies of the Late Triassic R. contorta facies in the Northern Apennines: II. The Monte Cetona Formation. Rev. Paléobiol. 13, 319-339.

Clement-Westerhof, J.A., Van der Eem, J.G.L.A., Van Erve, A.W., Klasen, J.J., Schuurman, W.M.L., Visscher, H., 1974. Aspects of Permian, Triassic and Early Jurassic Palynology of western Europe -a research project. Geol. Mijnbouw 53, 329-341.

Conway, B.H., Cousminer, H.L., Eshet, Y., Hirsch, F., 1990. Palynozones at the Triassic/Jurassic boundary in Israel. Cah. Univ. Cathol. Lyon, Sér. Sci. 3, 137-149.

Dubar, G., Mouterde, R., Llopis, N., 1963. Première récolte d'une Ammonite de l'Hettangien inférieur dans les calcaires dolomitiques de la region d'Avilés (Asturies, Espagne du Nord). C. R. Acad. Sci. Paris 257, 2306-2308.

Evitt, W.R., 1961. The dinoflagellate Nannoceratopsis Deflandre: morphology, affinities and infraespecific variability. Micropaleontology 7, 305-316.

Fisher, M.J., 1972. Rhaeto-Liassic palynomorphs from the Barnstone Railway Cutting, Nottinghamshire. Mercian Geol. 4, 101-106.

Fisher, M.J., 1979. The Triassic palynofloral succession in the Canadian Arctic Archipelago. Am. Assoc. Stratigr. Palynol. Found. Contribut. Ser. 5B, 83-100.

Fisher, M.J., Bujak, J., 1975. Upper Triassic palynofloras from Arctic Canada. Geosci. Man. 11, 87-94.

Fisher, M.J., Dunay, R.E., 1981. Palynology and the Triassic/Jurassic boundary. Rev. Palaeobot. Palynol. 34, 129-135.

Fowell, S.J., Olsen, P.E., 1993. Time calibration of Triassic-Jurassic microfloral turnover, eastern North America. Tectonophysics 222, 361-369.

Fowell, S.J., Cornet, B., Olsen, P.E., 1994. Geologically rapid Late Triassic extinctions: palynological evidence from the Newark Supergroup. Spec. Pap.-Geol. Soc. Am. 288, 197-206.

Francis, J.E., 1983. The dominant conifer of the Jurassic Purbeck Formation, England. Palaeontology 26, 277-294.

Fréchengues, M., Peybernés, B., Fournier-Vinas, C., 1992. Micropaléontologie des deux séquences de dépôt rétiennes des plis de Saint-Chinian (Bas-Languedoc, Hérault). Geobios 25, 457-467.

Fréchengues, M., Peybernés, B., Fournier-Vinas, C., Lucas, Cl., 1993. Palynologic assemblages within the depositional sequences from the Middle to Late Triassic series of the Spanish and French Pyrenees. Rev. Esp. Micropaleontol. 25, 91-105.

Gaetani, M., Lozowski, V., Szulc, J., Arche, A., Calvet, F., LópezGómez, J., Hirsch, F., 2000. Early Ladinian. In: Decourt, J., Gaetani, M., Vrielynck, B., Barrier, E., Biju-Duval, M.F., Brunet, M.F., Cadet, J.P., Crasquin, S., Sandulescu, M. (Eds.), Peri-Tethys Atlas, Palaeogeographical Mapas. CCGM/CGMW, Paris, pp. $41-48$.

Gómez, J.J., Goy, A., 2005. Late Triassic and Early Jurassic palaeogeographic evolution and depositional cycles of the Western Tethys Iberian plarform system (Eastern Spain). Palaeogeogr. Palaeoclimatol. Palaeoecol. 222, 77-94.

González, B., Menéndez Casares, E., García-Ramos, J.C., 2004. Subunidades litoestratigráficas de la Formación Gijón (Triásico Superior-Jurásico Inferior) en Asturias. Geo-Temas 6, 71-74.

Grignac, C., Taugourdeau-Lantz, J., 1982. Découverte de microflores d'âge hettangien dans l'épandage gréso-conglomératique "triasique" formant la base du Mésozoïque de la région de FigeacCapdenac (Quercy). C. R. Acad. Sci. Paris 295, 57-62.

Guex, J., Bartolini, A., Atudorei, V., Taylor, D., 2004. High-resolution and carbon isotope stratigraphy across the Triassic-Jurassic boundary at New York Canyon (Nevada). Earth Planet. Sci. Lett. 225, 29-41.

Gutiérrez Claverol, M., Manjón, M., 1984. Los depósitos evaporíticos del tránsito Permotrías-Lías en Asturias (Mina Felisa). Rev. Minas 4, 37-94.

Guy-Ohlson, D., 1981. Rhaeto-Liassic palynostratigraphy of the Valhall bore No 1, Scania. Geol. Fören. Stockh. Förh. 103, 233-248.

Guy-Ohlson, D., 1986. Jurassic Palynology of the Vilhelmsfält Bore No. 1, Scania, Sweden Toarcian-Aalenian. Section of Palaeobotany, Swed. Mus. Nat. Hist., Stockholm. 127 pp.

Hallam, A., 1989. The case for sea-level change as a dominant causal factor in mass extinction of marine invertebrates. Philos. Trans. R. Soc. Lond., B Biol. Sci. 325, 437-455.

Hallam, A., 1990. Correlation of the Triassic-Jurassic boundary in England and Austria. J. Geol. Soc. (Lond.) 147, 421-424. Hallam,

A., 1995. Major bio-events in the Triassic and Jurassic. In: Walliser, O.H. (Ed.), Global Events and Event Stratigraphy. Springer-Verlag, Berlin, pp. 238-265.

Hallam, A., 1998. Mass extinction in Phanerozoic time. In: Grady, M. M., Hutchinson, R., McCall, G.J.H., Rothery, D.A. (Eds.), Meteorites: Flux with Time and Impact Effects. Geol. Soc. London Spec. Publ., vol. 140, pp. 259-274.

Hallam, A., Wingall, P.B., 1999. Mass extinction and sea-level changes. Earth-Sci. Rev. 48, 217-250.

Hallam, A., Wignall, P.B., 2000. Facies changes across the TriassicJurassic boundary in Nevada, USA. J. Geol. Soc. (Lond.) 157, 49-54.

Harris, T.M., 1931. The fossil flora of Scoresby Sound, East Greenland: Part 1. Cryptogams (exclusive of Lycopodiales). Medd. Gronl., Geosci. 85, 1-104.

Harris, T.M., 1974. Williamsonilella lighieri: its pollen and the compression of spheroid pollen grains. Palaeontology 17 , 125-148.

Hesselbo, S.P., Robinson, S.A., Surlyk, F., Piasecki, S., 2002. Terrestrial and marine extinction at the Triassic-Jurassic boundary synchronized with major carbon-cycle perturbation: 
a link to initiation of massive volcanism? Geology 30, 251-254.

Hesselbo, S.P., Robinson, S.A., Surlyk, F., 2004. Sea-level changes and facies development across potential Triassic-Jurassic boundary horizons, SW Britain. J. Geol. Soc. (Lond.) 161, 365-379.

Holser, W.T., Clement, G.P., Jansa, L.F., Wade, J.A., 1988. Evaporite deposits of the North Atlantic rift. In: Manspeizer, W. (Ed.), Triassic-Jurassic Rifting. Continental Breakup and the Origin of the Atlantic Ocean and Passive Margins: Part B. Dev. Geotecton., vol. 22, pp. 525-556.

Hounslow, M.H., Posen, P.E., Warrington, G., 2004. Magnetostratigraphy and biostratigraphy of the Upper Triassic and lowermost Jurassic succession, St. Audrie's Bay, UK. Palaeogeogr. Palaeoclimat. Palaeoecol. 213, 331-358.

Hubbard, R.N.L.B., Boulter, M.C., 1997. Mid Mesozoic floras and climates. Palaeontology 40, 43-70.

Hubbard, R.N.L.B., Boulter, M.C, 2000. Phytogeography and Paleoecology in Western Europe and Eastern Greenland near the Triassic-Jurassic boundary. Palaios 15, 120-131.

Jarzen, D.M., Nichols, D.J., 1996. Chapter 9. Pollen. In: Jansonius, J., McGregor, D.C. (Eds.), Palynology: Principles and Applications. Am. Assoc. Stratigr. Palynol. Found., vol. 1, pp. 261-291.

Jenkyns, H.C., 2003. Evidence for rapid climate change in the Mesozoic-Palaeogene greenhouse world. Philos. Trans. R. Soc. Lond., A 361, 1885-1916.

Kendall, A.C., Harwood, G.M., 1996. Marine evaporites: arid shorelines and basins. In: Reading, H.G. (Ed.), Sedimentary Environments: Processes, Facies and Stratigraphy, pp. 281-324.

Llopis, N., 1961. Estudio geológico de la región del Cabo Peñas. Bol. Geol. Min. 72, 235-348.

Lund, J.J., 1977. Rhaetic to Lower Liassic palynology of the onshore south-eastern North Sea Basin. Geol. Surv. Den. 109, 3-129.

Manjón, M., Gutiérrez Claverol, M., 1991. Nuevas precisiones sobre los depósitos de sulfatos de los alrededores de Gijón (Asturias). Geogaceta 9, 87-89.

Martínez García, E., Coquel, R., Gutiérrez Claverol, M., Quiroga, J.L., 1998. Edad del "tramo de transición" entre el Pérmico y el Jurásico en el área de Gijón (Asturias, NW de España). Geogaceta 24, 215-218.

Marzoli, A., Renne, P.R., Piccirillo, E.M., Ernesto, M., Bellieni, G., DeMin, A., 1999. Extensive 200-million-year-old continental flood basalts of the central Atlantic Magmatic province. Science 284, 616-618.

Marzoli, A., Bertrand, H., Knight, K.B., Cirilli, S., Buratti, N., Vérati, C., Nomade, S., Renne, P.R., Youbi, N., Martini, R., Allenbach, K., Neuwert, R., Rapaille, C., Zaninetti, L., Bellieni, G., 2004. Synchrony of the Central Atlantic magmatic province and the Triassic-Jurassic boundary climatic and biotic crisis. Geology 32, 973-976.

Mayal, M.J., 1981. The Late Triassic Blue Anchor Formation and the initial Rhaetian marine transgression in south-west Britain. Geol. Mag. 118, 377-384.

McElwain, J.C., Beerling, D.J., Woodward, F.I., 1999. Fossil plants and the global warming at the Triassic-Jurassic boundary. Science 285, 1386-1390.

Mohr, B.A.R., 1989. New palynological information on the age and environment of Late Jurassic and Early Cretaceous vertebrate localities of the Iberian Peninsula (eastern Spain and Portugal). Berl. Geowiss. Abh., Reihe A, Geol. Palaontol. 106, 291-301.
Morbey, S.J., 1975. The palynostratigraphy of the Rhaetian stage, Upper Triassic in the Kendelbachgraben, Austria. Palaeontogr., Abt. B 152, 1-75.

Morbey, S.L., Neves, R., 1974. A scheme of Palinologically defined concurrent-range zones and subzones for the Triassic Rhaetian Stage (sensu lato). Rev. Palaeobot. Palynol. 17, 161-173.

Orbell, G., 1973. Palynology of the British Rhaeto-Liassic. Bull. Geol. Surv. G. B. 44, 1-44.

Pálfy, J., Demény, A., Haas, J., Hetényi, M., Orchard, M.J., Vetö, I., 2001. Carbon isotope anomaly and other geochemical changes at the Triassic-Jurassic boundary from a marine section in Hungary. Geology 29, 1047-1050.

Pedersen, K.R., Lund, J.J., 1980. Palynology of the plant-bearing Rhaetian to Hettangian Kap Stewart Formation, Scoresby Sund, East Greenland. Rev. Palaeobot. Palynol. 31, 1-69.

Peybernes, B., Martini, R., Taugourdeau-Lantz, J., Zaninetti, L., 1988. Caractérisation micropaléontologique du Rhétien dans les Pyrénées françaises entre Garonne et Méditerranée. Rev. Paléobiol. 7, 137-161.

Phipps, D., Playford, G., 1984. Laboratory techniques for extraction of palynomorphs from sediments. Pap.-Dep. Geol., Univ. Qld. 11, $1-23$.

Pieren, A.P., Areces, J.L., Toraño, J., Martínez García, E., 1995. Estratigrafía y estructura de los materiales permotriásicos del sector Gijón-La Collada (Asturias). Cuad. Geol. Ibér. 19, 309-335.

Planderová, E., 1980. Palynomorphs from lunz beds and from black clayey shales in basement of Vienna Basin (Borehole LNV-7). Geol. Carpath. 31, 267-294.

Raup, D.M., 1992. Large-body impact and extinction in the Phanerozoic. Paleobiology 18, 80-88.

Reinhardh, L., Ricken, W., 2000. Climate cycles documented in a playa system: comparison of geochemical signatures derived from subbasins (Triassic, Middle Keuper, German Basin). Zlbl. Geol. Paläontol. 1, 315-340.

Rees, P.M., Ziegler, A.M., Valdes, P.J., 2000. Jurassic phytogeography and climates: new data and model comparisons. In: Hubert, B.T., MacLeod, K.G., Wing, S.L. (Eds.), Warm Climates in Earth History. Cambridge Univ. Press, Cambridge, UK, pp. 297-318.

Retallack, G.J., 2001. A 300-million-year record of atmospheric carbon dioxide from fossil plant cuticles. Nature 411, 287-289.

Robles, S., Quesada, S., Rosales, M., Aurell, M., García Ramos, J.C., 2004. El Jurásico marino de la Cordillera Cantábrica. In: Vera, J.A. (Ed.), Geología de España. SGE-IGME, pp. 279-285.

Roghi, G., 2004. Palynological investigations in the Carnian of the Cave del Predil area (Julian Alps, NE Italy). Rev. Palaeobot. Palynol. 132, 1-35.

Schulz, E., 1967. Sporenpaläontologische Untersuchungen rëtoliassischer Schichten im Zentralteil des Germanischen Beckens. Paläontol. Abh. B 2, 427-633.

Schultz, E., Heunisch, C., 2005. Palynostratigraphische Gliederungsmöglichkeiten des deutschen Keupers. In: Beutler, G. (Coord.), Stratigraphie von Deutschland IV Keuper. Cour. Forsch. - Inst. Senckenberg, 253, 43-49.

Schuurman, W.M.L., 1976. Aspects of Late Triassic palynology: 1. On the morphology, taxonomy and stratigraphical/geographical distribution of the form genus Ovalipollis. Rev. Palaeobot. Palynol. 21, 241-266.

Schuurman, W.M.L., 1977. Aspects of Late Triassic palynology: 2. Palynology of the "Grès et Schiste à Avicula contorta" and "Argiles de Levallois" (Rhaetian) of Northeastern France and Southern Luxemburg. Rev. Palaeobot. Palynol. 23, 159-253. 
Schuurman, W.M.L., 1979. Aspects of Late Triassic palynology: 3. Palynology of latest Triassic and earliest Jurassic deposits of the northern limestone Alps in Austria and southern Germany, with special reference to a palynological characterization of the Rhaetian stage in Europe. Rev. Palaeobot. Palynol. 27, 53-75.

Srivastava, S.K., 1987. Jurassic spore-pollen assemblages from Normandie (France) and Germany. Geobios 20, 5-79. Steinhoff,

I., Strohmenger, C., 1999. Facies differentiation and sequence stratigraphy in ancient evaporite basins-an example from the basal Zechstein (Upper Permian of Germany). Carbonates Evaporites 14, 146-181.

Stover, L.E., Brinkhuis, H., Damassa, S.P., de Verteuil, L., Helby, R.J., Monteil, E., Partridge, A.D., Powell, A.J., Riding, J.B., Smelror, M., Williams, G.L., 1996. Mesozoic-Tertiary dinoflagellates, acritarchs and Prasinophytes. In: Jansonius, J., McGregor, D.C. (Eds.), Palynology: Principles and Applications. Am. Assoc. Stratigr. Palynol. Found., vol. 2, pp. 641-750.

Suarez Vega, L.C., 1969. El Lías de Asturias. Semin. Estratigr. 4, 41-46.

Suárez Vega, L.C., 1974. Estratigrafía del Jurásico de Asturias. Cuad. Geol. Ibér. 3, 1-368.

Tanner, L.H., Hubert, J.F., Coffey, B.P., Mclnerney, D.P., 2001. Stability of atmospheric $\mathrm{CO}_{2}$ levels across the Triassic/Jurassic boundary. Nature 411, 675-677.

Tanner, L.H., Lucas, S.G., Chapman, M.G., 2004. Assessing the record and causes of Late Triassic extinctions. Earth-Sci. Rev. 65, 103-139.

Thierry, J., 2000. Late Sinemurian. In: Decourt, J., Gaetani, M., Vrielynck, B., Barrier, E., Biju-Duval, M.F., Brunet, M.F., Cadet, J. P., Crasquin, S., Sandulescu, M. (Eds.), Peri-Tethys Atlas, Palaeogeographical Mapas. CCGM/CGMW, Paris, pp. 49-59.

Vachard, D., Colin, J.-P., Hochuli, P.A., Rosell, J., 1990. Biostratigraphie: foraminifères, palynoflore et ostracodes du Rhétien de Bac Grillera (Pyrénées Orientales espagnoles). Geobios 23, 521-537.
Vakhrameev, V.A., 1991. Jurassic and Cretaceous Floras and Climates of the Earth. Cambridge Univ. Press, Cambridge. 318 pp.

Valenzuela Fernández, M., 1988. Estratigrafía, sedimentología y paleogeografía del Jurásico de Asturias. Ph.D. thesis. Univ. Oviedo, Spain.

Valenzuela, M., García-Ramos, J.C., Suarez de Centi, C., 1986. The Jurassic sedimentation in Asturias (N Spain). Trab. Geol. 16, 133-137.

Van Konijnenburg-Van Cittert, J.H.A., 2002. Ecology of some Late Triassic to Early Cretaceous ferns in Eurasia. Rev. Palaeobot. Palynol. 119, 113-124.

Visscher, H., Brugman, W., 1981. Ranges of selected palynomorphs in the Alpine Triassic of Europe. Rev. Palaeobot. Palynol. 34, 115-128.

Ward, P.D., Haggart, J.W., Carter, E.S., Wilbur, D., Tipper, H.W., Evans, T., 2001. Sudden productivity collapse associated with the Triassic-Jurassic boundary mass extinction. Science 292, 1148-1151.

Warren, J.K., Kendall, G.S.T.C., 1985. Comparison of sequences formed in marine sabkha (subaerial) and salina (subaqueous) settings - modern and ancient. AAPG Bull. 69, 1013-1023.

Warrington, G., Harland, R., 1975. Palynology of the Trias and Lower Lias of the Larne borehole. Bull. Geol. Surv. G. B. 50, 37-49.

Warrington, G., Cope, J.C.W., Ivimey-Cook, H.C., 1994. St. Audrie's Bay, Somerset, England: a candidate global stratotype section and point for the base of the Jurassic System. Geol. Mag. 133, 191-200.

Watson, J., 1988. The Cheirolepidiaceae. In: Beck, C.B. (Ed.), Origin and Evolution of Gymnosperms. Columbia Univ. Press, New York, pp. 382-447.

Weems, R.E., 1992. The "terminal Triassic catastrophic extinction event" in perspective: a review of Carboniferous through Early Jurassic terrestrial vertebrate extinction patterns. Palaeogeogr. Palaeoclimat. Palaeoecol. 94, 1-29. 